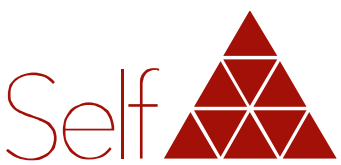

Revista do Instituto Junguiano de Săo Paulo

\title{
O padre, o psiquiatra e o problema do mal $^{1}$
}

\section{Punita MIRANDA}

The Guild of Analytical Psychology, Londres, Reino Unido punita.miranda@gmail.com

Artigo originalmente publicado em inglês, no periódico Phanês. Tradução de Sonia Maria Caiuby Labate? .

\section{Resumo}

Este artigo trata do problema do mal dentro do quadro de referência da psicologia profunda. A primeira parte introduz, de modo breve, a narrativa do livro de "Jó" como um exemplo para contextualizar a questão fundamental da relação de Deus com o mal e de como ela permaneceu não respondida e foi deixada em aberto na teologia cristã. A segunda parte reconstrói, historicamente, a polêmica não resolvida a respeito da natureza do mal entre Carl Jung (1875-1961) e o scholar, teólogo e dominicano inglês, Victor White (1902-1960). Examina as diferentes especulações e formulações que ambos fizeram relativas ao mal e suas implicações psicológicas, até a ruptura final, após a severa resenha crítica de White a respeito da obra mais controversa de Jung sobre religião, "Answer to Job". A parte final deste artigo introduz reflexões adicionais a um tema desafiador que é tão poderoso e relevante no mundo atual de terrorismo em nome da religião, quanto o era na Europa do pós-guerra, que lutava para recuperar-se do totalitarismo e do genocídio.

Palavras-Chave: Carl Jung, Victor White, livro de "Jó", "Answer to Job", mal.

\footnotetext{
${ }^{1}$ Miranda, P. (2019). The priest, the psychiatrist and the problem of evil. Phanês: Journal and Network for Jung History 2, 101-141. https://doi.org/10.32724/phanes.2019.Miranda

${ }^{2}$ Mantivemos em inglês os títulos de todas as obras referenciadas no texto, pois, as obras originais consultadas para a elaboração do artigo estão no idioma inglês, assim como a lista final de referências.
} 


\title{
The priest, and psychiatrist and the problem of the evil
}

\begin{abstract}
This paper clusters around the problem of evil within the framework of depth psychology. The first part briefly introduces the narrative of the Book of Job as an example to contextualise how the ultimate question of God's relation to evil remained unanswered and was left open-ended in Christian theology. The second part offers a historical reconstruction of the unresolved polemic over the nature of evil between Carl Jung and the English Dominican scholar and theologian Victor White (1902-1960). It explores their different speculations and formulations concerning evil and its psychological implications, until their final fall-out following White's harshly critical review of Jung's most controversial work on religion, Answer to Job. The final section of this paper introduces further reflections on a challenging theme that is no less resonant and relevant in today's world of terrorism in the name of religion than it was in a post-war Europe struggling to recover from totalitarianism and genocide.
\end{abstract}

Keywords: Carl Jung, Victor White, "Book of Job", "Answer toJob", evil. 


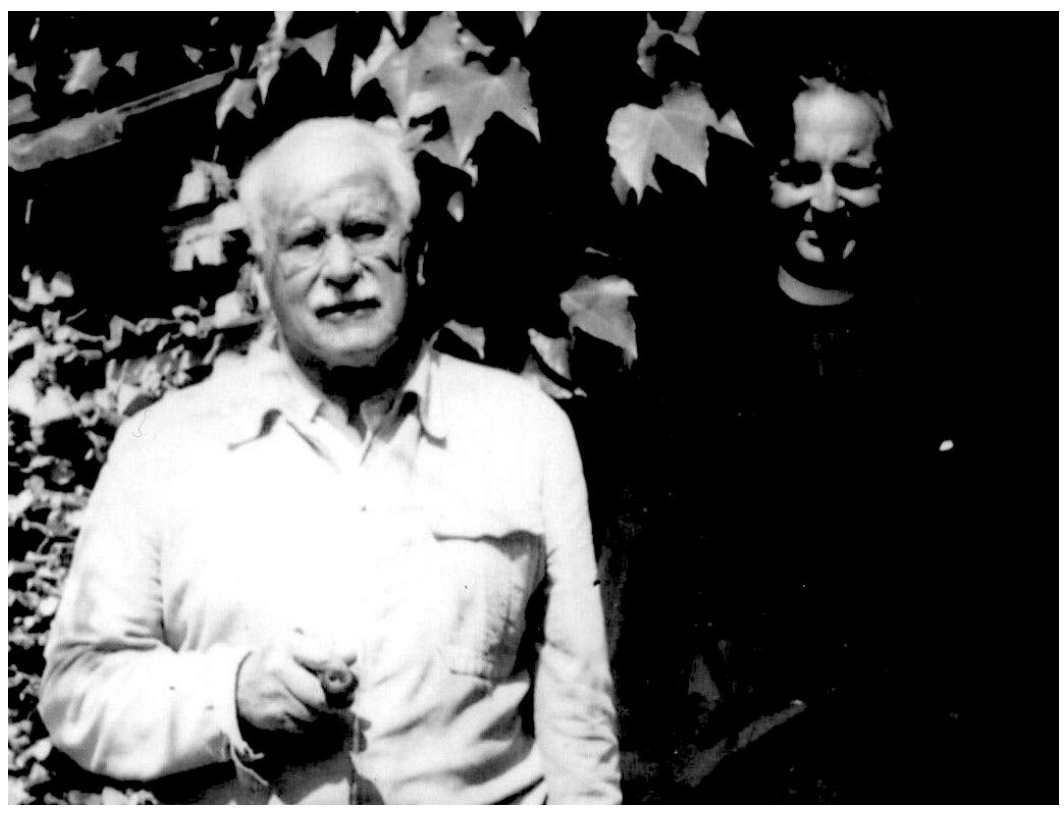

C. G. Jung e Padre Victor White em Bollingen, cerca de 1946

Deus fez-me cair nas mãos dos ímpios

E atirou-me nas garras dos maus.

Eu estava tranquilo, mas ele me arrebentou;

Agarrou-me pelo pescoço e esmagou-me.

Fez de mim o seu alvo; seus flecheiros me cercam.

Ele traspassou sem dó os meus rins e derramou na terra a minha bílis.

Lança-se sobre mim uma e outra vez; ataca-me como um guerreiro. Costurei veste de lamento sobre a minha pele e enterrei a minha testa no pó.

Meu rosto está rubro de tanto eu chorar, e sombras densas circundam os meus olhos; apesar de não haver violência em minhas mãos

e de ser pura a minha oração (Jó 16:11-17). (Bíblia Sagrada online NVI https://www.bibliaon.com/jo_16/) 
O livro de "Jó" (600-300 a.C.) faz parte dos livros de "sabedoria" (do grego, "Sophia") da Bíblia judaico-cristã e tem sido admirado universalmente como uma "obra-prima literária" da "maior magnitude", de diálogos poéticos e de prosa narrativa (Bishop 2002:3, Parsons 1981 :213). Provavelmente sua composição data do século 5, entre o holocausto babilônico e o período total do exílio (587-538 a.C.). O livro divide-se em cinco partes: (i) o prólogo na terra e no cév; (ii) simpósio - diálogos entre Jó e seus três amigos; (iii) três monólogos: poema sapiencial, monólogo final de Jó e os discursos de Eliú; (iv) diálogo com Deus; e (v) epílogo (Chase 2013:5). A figura de Jó em contextos judaicos e não judaicos inspirou muitos filósofos, pensadores religiosos e intelectuais, bem como capturou a imaginação de pintores e músicos ${ }^{3}$. A virtude exemplar de Jó, com suas contínuas variações de interpretação, desde cerca do século 6, tornouse um modelo infindável na contemplação da inescrutabilidade da Providência Divina.

O livro de "Jó" é uma história trágica de sofrimento, infortúnio e resiliência. O justo e fiel Jó torna-se vítima de uma aposta entre Javé e Satanás (Jó 1:6-12). Durante essa provação, Satanás desafia a devoção de Jó, e Deus permite que ele inflija a Jó intensa dor física, perda emocional e luto (Jó 1:13-20; 2:7). Jó não consegue ver justiça em seu sofrimento, contudo tenta compreender por que está sendo punido, uma vez que não pecou. Três amigos, Elifaz, Bildade e Zofar, primeiramente vêm confortá-lo (Jó 2:11), mas, em seguida, argumentam que Javé está além da compreensão humana (Jó 22) e que talvez Jó esteja sofrendo por causa de um "pecado oculto" (Jó 4:7-21; 11:7; 15;18) (Parsons 1981: 144). Mais uma vez Jó afirma sua inocência (Jó 6:24-30; $7: 11 ; 10: 2$ ). Face ao silêncio e ausência de Deus (Jó 23), Jó é tomado pela raiva e, por meio de suas queixas e tormento interminável (Jó 16, 19), reafirma sua inocência (Jó 31 ), defendendo sua causa "diante de Deus contra Deus" (Jó 13:3), que fica indiferente à sua tribulação (Jó 27). Em sua revolta contra Deus, Jó apresenta seu protesto (Jó 13:18; 31 ; 35) e exige saber onde se deve encontrar a sabedoria (Jó 28). Deus ignora seu apelo (Jó 30:20; $31: 35)$. As únicas respostas que Jó recebe são algumas observações raivosas de outro amigo, Eliú (Jó 32 37), e a aparição de Deus em um redemoinho, mostrando aspectos de Sua criação, de estrelas a animais, incluindo monstros como Behemoth e Leviatã (Jó 38-41). Após contemplar o cosmos, Jó arrepende-se e submete-se à supremacia de Deus (Jó 42:1-6). Javé então recompensa-o por sua fé e resistência. Seu sofrimento é removido e sua restauração inclui saúde, o dobro das propriedades anteriores, novos filhos e uma vida extremamente longa (Jó 42:7-17).

O livro de "Jó" oferece uma reflexão duradoura sobre como um Deus bom pôde produzir atos de maldade. Além disso, retrata, de maneira muito individual, a natureza do sofrimento humano e analisa profundas questões a respeito de recompensas e punições e a relação entre sofrimento e pecado, fé e esperança. Jó, como um sofredor inocente, por um lado, teve que suportar, de maneira submissa, uma prova de sinceridade, mas, por outro lado, como um rebelde, confrontou Deus diretamente, questionando Suas punições injustas. Dessa maneira, o flagelo de Jó ilustra o sofrimento imerecido da humanidade; seu grito, desafiando a relação humano-divina, ecoa ainda hoje e nunca perdeu sua vitalidade. É esse aspecto da audácia de Jó que Jung elaborou ainda mais em seu livro

\footnotetext{
${ }^{3}$ Para uma lista completa de comentários sobre o livro de "Jó", confira Bishop 2002:4-14. Para exemplos visuais e musicais, confira especialmente as 19 ilustrações em aquarela e as 22 gravuras de William Blake (1757-1827) do livro de "Jó"; as duas litografias de Marc Chagall (1887-1985): "Job Praying" e "Job in Despair"; uma tapeçaria chamada "Job", dedicada a todos as pessoas com deficiência do mundo; e a suíte de Vaughan Williams (1872-1958): "Job: A Masque for Dancing".
} 
"Answer to Job"4. Jung acreditava que a história de Jó e seu questionamento a Deus prefiguraram questões existenciais modernas sobre o altamente controverso Deus todo-bom, que nunca deu uma resposta adequada quer para o problema do mal, quer para Sua cumplicidade sobre a origem e a presença do mal no mundo.

Os opostos de bem e mal, do ponto de vista psicológico, correspondem aos aspectos positivos e negativos da natureza humana. A questão das forças destrutivas que se manifestam nos indivíduos e como fenômeno grupal foi recentemente discutida em dois conjuntos de ensaios: "Ethics of Evil"; e "Humanizing Evil: Psychoanalytic, Philosophical and Clinical Perspectives", ambos editados pelos psicanalistas Ronald C. Naso e Jon Mills, em 2016. Os textos exploram e examinam as controvérsias a respeito das definições de mal, a pluralidade de suas manifestações no mundo e a ligação intrínseca entre liberdade humana e o potencial para o mal. Em distinto contraste com a abordagem integrativa da psicologia profunda sobre o mal, discutida nesses ensaios, este artigo reconsidera a envolvente narrativa de Javé-Jó, na qual Jung afasta-se de considerações metafóricas de Deus e do mal e aborda questões de responsabilidade coletiva. Jung declara que todos nós somos, não apenas capazes de cometer crimes individuais, como somos também coletivamente responsáveis pelas ações destrutivas da humanidade. Um caso em tela, a ser discutido mais adiante, é sua perspectiva do "deus tenebroso [que] colocou-lhe nas mãos a bomba atômica e o material para uma guerra química, dando-lhe assim o poder de despejar a taça da ira apocalíptica sobre seus semelhantes" (Jung 1952, ATJ, CW1 1 :§747). Para Jung, a possibilidade de destruição universal por meio da bomba atômica deu ao homem um "poder quase divino"; porém, permanece a questão: temos a maturidade moral de lidar com tal responsabilidade?

\section{Resposta ao mal}

Naturalmente, podemos acreditar que Deus é diferente da imagem que dEle fazemos, mas, deve-se admitir, por outro lado, que o Senhor mesmo, ao insistir na bondade perfeita do Pai, deu-nos uma descrição dEle que dificilmente coincide com a ideia de um ser moralmente perfeito: (um pai que induz em tentação os seus filhos, que não desfaz o erro de uma parusia imediata, que está tão cheio de ira que é necessário o sangue de seu único filho para apaziguá-lo, que deixou entregue o crucificado ao desespero, que há de arrasar sua própria criação e matar milhares de pessoas para salvar apenas um pequeno rebanho, que antes do fim do mundo vai substituir o testamento de seu Filho por outro evangelho e que complementará o amor através do temor de Deus). É interessante, ou antes trágico, que Deus sofra uma recaída total no último livro

\footnotetext{
4"Antwort auf Hiob" foi publicado pela primeira vez em 1952 em Zurique; em seguida, foi traduzido de maneira particular para o inglês com o título de "Answer to Job" pelo analista judeu, Dr. James Kirsch, para um seminário realizado em Los Angeles em 1952-1953 para um número limitado de analistas em treinamento. Em 1953, para a segunda edição de "Answer to Job", Jung incorporou as correções sugeridas por Kirsh. A tradução atual, feita por R. F. C. Hull, foi publicada pela primeira vez em Londres, em 1954, e reimpressa em 1956 pelo Pastoral Psychology Book Club em New York. O livro agora faz parte de "The Collected Works of C. G. Jung: Psychology and Religion West and East", volume 11, impressa em 1958; e no Brasil foi publicado em 1979, pela Vozes. Para mais informações, confira Jung, "Letters", vol. 2:104; Jung, CW1 1 :vii; Lammers (2007a:254, n5).
} 
do Novo Testamento (Jung para Père Lachat, 27 março de 1954, CW18: §1556).

Com uma educação cristã, Jung tinha um longo envolvimento com a questão do mal, e seu problema desempenha um papel importante na psicologia profunda, estando ela particularmente preocupada com o que está à espreita, abaixo do nível da consciência. Jung usou o termo sombra para descrever as partes ocultas, escuras e inferiores da personalidade. Esses conteúdos, pulsões ou impulsos podem ser experimentados como "maus" ou o "mal" e por isso são reprimidos e cindidos devido à sua natureza conflitante e incompatível com os valores pessoais e/ou com os códigos morais coletivos. Jung acreditava que o cristianismo reprimiu o instinto animal e negligenciou a tarefa de lidar com o mal, especialmente pela "tremenda compulsão da consciência para o bem" (Jung CW10: §20). Sua psicologia oferece a possibilidade de assimilação e de transformação do mal por meio de um processo de integração psicológica do significado compensatório do que está na sombra ${ }^{5}$. Jung leu o livro de "Jó" pela primeira vez quando ainda criança e com choque descobriu que Javé era injusto, um vilão sem consideração pelo sofrimento humano (Jung, em McGuire 1977:225-234). Em sua "autobiografia", Jung relata que se tivesse ouvido como "o Deus todo-poderoso pode operar Sua vontade terrífica em seres humanos indefesos", isto poderia ter "aberto seus olhos" para compreender se tinha sido Deus ou o demônio que o confrontou com seu sonho do falo devorador de homens (entre os três e quatro anos) e com a visão de Deus (aos 12 anos) destruindo Sua própria igreja ao defecar no teto da Catedral da Basileia, despedaçando-a (Jung, MDR: $64 ; 26-28 ; 52-56)^{6}$. Lá pelos 16 anos, ele já estava "seriamente duvidando da bondade de Deus", especialmente devido ao fato de Ele Próprio ter colocado no Éden "aquela serpente venenosa, o demônio", corrompendo a glória do paraíso. Jung finalmente descobriu no "Fausto" de Goethe a confirmação de seus sentimentos a respeito do poderoso sentido da realidade do mal: "Enfim, eis um homem que leva o Demônio a sério e que efetua com ele um pacto de sangue. Afinal é um adversário que tem o poder de contrariar a intenção divina de criar um mundo perfeito" (Jung, MDR:76-77).

Embora as narrativas do Fausto e de Jó sejam bem diferentes, seu paralelo é importante porque ambas têm como base a mesma premissa de uma barganha sendo feita com Satanás. John Williams, um dos tradutores do "Fausto" de Goethe, assinalou que Goethe usou o "modelo estabelecido no Livro de Jó (1:6-12) para sugerir a possibilidade da danação de Fausto" (Williams 2007: xv). Jung também observou que "Fausto é apresentado como Jó" (Jung 1949, "Faust and Alchemy", CW18: §1694) ${ }^{7}$. Como psiquiatra, Jung preocupava-se não apenas com o efeito do mal na vida individual e na sociedade, mas igualmente com o papel que ele desempenha na religião. Suas obras da maturidade frequentemente criticaram os pressupostos ingênuos da

${ }^{5} \mathrm{~A}$ respeito da sombra individual e coletiva em Jung, confira Jung, "The Archetypes and the Collective Unconscious", (1934/1954, CW9i: §§§1-86); "Aion: Researches into the Phenomenology of the Self", (1951, CW9ii: §§13-19); "The Role of the Unconscious" (1918, CW10: §§1-48); "After the Catastrophe" (1945, CW10: §§400-443); "The Fight with the Shadow" (1946, CW10: §§444-457). Sobre consciência e comportamento ético em Jung, confira "A Psychological View of Conscience" (1958, CW10: §§825-857) e "Good and Evil in Analytical Psychology" (1959, CW10: §§858-886).

${ }^{6}$ Cito "Memories, Dreams, Reflections", de Jung (doravante MDR), ciente do artigo de Shamdasani "Memories, Dreams, Omissions" (Shamdasani 1995), onde ele esclarece que MDR de Jung deve ser lida não como uma "autobiografia" e sim como uma "biografia".

${ }^{7}$ Para mais informações, confira Edinger 1992b:88; Stein 2007:313. 
doutrina cristã a respeito do $\mathrm{mal}^{8}$, junto com suas considerações sobre "a resposta ainda por encontrar à questão dos gnósticos sobre a origem do mal" (Jung MDR: 350), enfatizando como a "falta de insight nos priva de lidar com ele"(Jung CW10: §572). Jung tinha grande interesse pelo pensamento dos primeiros escritores gnósticos cristãos que reconheciam a igualdade do bem e do mal:

É patente o dualismo dos sistemas gnósticos, os quais procuram fazer justiça ao real significado do mal. Esses sistemas possuem também o mérito de terem sido os primeiros a se ocuparem do problema da origem do mal; [...] em um sistema monoteísta tudo que se opõe a Deus não pode derivar senão do próprio Deus (Jung 1942/1948, CW1 1: §249).

Oencontro inicial de Jung com a tradição gnóstica deu-se em 1911, enquanto escrevia "Transformations and Symbols of the Libido" (1911-12), e ele discutiu o gnosticismo em toda a sua obra. Em 1952, o Instituto C. G. Jung, em Zurique, comprou um dos manuscritos gnósticos então descobertos em Nag Hammadi (Egito); ele foi chamado de "Jung Codex", em homenagem à significativa pesquisa e ao comprometimento de Jung com o gnosticismo. Shamdasani mostrou que "The Red Book" e "The Black Books" tornaram evidente que Jung buscava paralelos históricos para as suas próprias experiências nos escritores gnósticos, quando se aprofundou nesse estudo, durante seu serviço militar em janeiro e outubro de 1915. Em 1916, Jung escreveu os "Seven Sermons to the Dead" ("Septem Sermones ad Mortuos"), uma cosmologia "psicoteológica" semelhante ao antigo mito gnóstico. Em "Memories", Jung posteriormente esclareceu: "De 1918 a 1926, lancei-me seriamente ao estudo dos gnósticos, pois também eles haviam se confrontado com o mundo original do inconsciente" (Jung MDR: 226). Para Jung, os gnósticos mereciam o crédito de terem descoberto expressões simbólicas apropriadas para o Self, para o conflito dos opostos, e na figura de Abraxas viu a representação da união do Deus cristão com Satanás (Shamdasani 2009: 205-6). O público e notório interesse de Jung pelo gnosticismo gerou debates, comentários e vários mal-entendidos 9 .

O filósofo judeu Martin Buber (1878-1965) acusou a psicologia de Jung de ser um ressurgimento do gnosticismo e manteve uma controvérsia após a publicação de "Answer to Job"

\footnotetext{
${ }^{8} \mathrm{~A}$ primeira polêmica pública de Jung contra o tratamento católico do mal como uma privatio boni pode ter sido sua palestra "Zur Psychologie der Trinitätsidee", em Eranos, em 1940 ex tempore; a versão impressa no "Eranos-Jahrbuch 1947" tinha sido reconstruída a partir de anotações de seus ouvintes. Em 1947, ele a revisou e expandiu para republicação, agora parte de "Psychology and Religion: West and East" (CW1 1: $\S \S 169-295)$, citado também em Lammers 2005:20, 79 n51.

"Para uma lista abrangente de estudiosos que escreveram sobre "Seven Sermons to the Death" de Jung e sua ligação com o gnosticismo anteriormente à publicação do "Red Book", ver: Shamdasani, "The Red Book", p. 346, n. 81. Para comentários posteriores à publicação do "Red Book", ver especialmente: Maillard, "Au Cœur du Livre Rouge: Les Septs Sermons aux morts"; Owens, "The Hermeneutics of Vision: C. G. Jung and Liber Novus", pp. 23-46; Maillard, "La penseé de Carl Gustav Jung et les courants néo-gnostiques de la première moitié du XXème siècle", pp. 99-116; Idem, "Seven Sermons to the Dead" de Jung (1916), "A Gnosis for Modernity: a Multicultural Vision of Spirituality" (1916), pp. 81-93; Drob, "Reading the Red Book", pp. 201-57. Ver também Ribi, "The Search for Roots: C. G. Jung and the Tradition of Gnosis", pp. 1-33, onde Owens complementa a edição alemã anterior, oferecendo no prefácio uma longa discussão do "Red Book" e o encontro inicial de Jung com a tradição gnóstica.
} 
(Buber 1952:63-93, 131-139; Jung 1952, CW18: §§1499-1513)10. Para Jung, o mal é uma força em si mesma e argumentou que a doutrina da lgreja da privatio boni, na qual o mal é simplesmente a ausência do bem, é uma "tentativa desesperada de salvar a fé cristã do dualismo" (Jung 1958, CW18: §1593). Jung também formulou que isso é um dilema metafísico desafiador: "ou há um dualismo e a Onipotência de Deus está dividida em dois, ou os opostos estão contidos na Imago Dei monoteísta" (Jung 1958, CW10: §844). Esse assunto será discutido na próxima parte deste ensaio, uma vez que foi exatamente o impasse a respeito da natureza do mal o principal traço do longo debate entre Jung e Victor White, que culminou na "Answer to Job".

Jung não abordou de forma leviana quer a relação do mal com Deus, quer a negligência do potencial humano em ser um instrumento do mal. Seu comprometimento com essa questão deu-se no cenário do mundo no qual viveu: desde o início da Primeira Guerra Mundial ${ }^{11}$ - quando chegou à conclusão de que as visões perturbadoras que teve antes da guerra tinham sido proféticas -, até a "época catastrófica" da Segunda Guerra Mundial, que testemunhou "uma fúria de destruição sem precedentes" (Jung 1916, "Preface to the First Edition" de "On the Psychology of the Unconscious", CW7: §§1-201). Até o período anterior ao fim de sua vida em 1961, dominado pelas tensões econômico-ideológicas e pela escalada nuclear da Guerra Fria, Jung continuou a ocupar-se em escrever ensaios relativos ao significado dos eventos apocalíticos (Jung 1945/1946, CW10: §§371-487). Falou não somente sobre a condição mental do ocidente, mencionando a cisão patológica no homem, que tende a "tornar seu vizinho responsável por suas próprias qualidades malignas" (Jung 1916, "Preface to the First Edition" de "On the Psychology of the Unconscious"), como também examinou o ponto de vista metafísico cristão sobre o mal que "liberou a consciência humana de uma responsabilidade demasiadamente pesada" (Jung 1956/1957, CW10: §573). Em uma carta a Victor White em 1949, falou de maneira categórica e direta:

Enquanto o Mal for um "não-ser", ninguém levará sua própria sombra a sério. Hitler e Stalin seguem representando apenas uma "falta acidental de perfeição". O futuro da humanidade depende fortemente do reconhecimento da sombra. O Mal é - em termos psicológicos — terrivelmente real (Jung, em Lammers 2007a:143).

Jung usou símbolos bíblicos como chaves para interpretar os agentes psicológicos na psique humana; acreditava que a possibilidade de uma destruição universal por meio da bomba atômica tinha conferido ao ser humano um "poder por assim dizer divino" (Jung 1959, CW10: §879; também Jung 1952, ATJ, CW 11: §747) e que as consequências de ter tanto poder sobre a natureza o sobrecarregava com um "alto grau de responsabilidade ética" (Jung 1946, CW10: $\S 451)$. Era de opinião que os seres humanos não podiam mais dar-se ao luxo de negar sua justa participação nos feitos malignos; ou seja, que faz parte da tarefa humana reconhecer que até a sombra mais tenebrosa representa um aspecto de cada um de nós. A ideia de o mal estar contido em Deus foi antecipada nos capítulos "Hell" e "The Sacrificial Murder" de seu "Red Book". Jung percebeu que como seres humanos somos todos não apenas capazes de cometer crimes, mas também responsáveis por nossos feitos coletivos. Jung usou a analogia da famosa citação do dramaturgo romano Terêncio (cerca de 186-159 a.C.) que aparece em "Heautòn Timoroûmenos" (O carrasco de si) - "Sou homem. Nada de humano me é estranho", para ilustrar

\footnotetext{
${ }^{10}$ Para um relato abrangente do diálogo entre os estudos junguianos e gnósticos, ver Ribi 2013.

${ }^{11}$ Jung serviu o exército de forma ativa durante a Primeira Guerra Mundial: em 1914, 14 dias; em 1915, 67 dias; em 1916, 34 dias; em 1917, 117 dias, citado em Shamdasani 2009:201.
} 
essa ideia. Acreditava até que era seu dever, como médico e psicólogo, ser capaz de compreendê-la (Jung, RB:290, n149). Jung posteriormente elaborou isso como um "instinto criminoso não satisfeito em nós mesmos" (Jung 1989: 471) e esclareceu: "Deus pode ser chamado de bom apenas na medida em que Ele é capaz de manifestar Sua bondade nos indivíduos. Sua qualidade moral depende dos indivíduos" (Jung, "Letters", vol. 2:314). Para Jung, o homem foi enredado no dinamismo do drama divino, e somos agora responsáveis por "encarnar" o lado sombrio de Deus. Constatou que a natureza moral paradoxal de Javé "traz consequências para a humanidade", uma vez que também nós somos "obrigados a lutar com o demônio", sob a forma de um conflito interior que pode destruir a integridade do homem (Jung 1977:226, 230; também 186-189). Assim, a conspiração divina entre Javé e Satanás contra Jó serviu psicologicamente para Jung não apenas como uma ilustração, mas também como uma advertência.

\section{Resposta a Jó}

É lamentável que o senhor não tenha lido minhas notas introdutórias. Teria descoberto ali meu ponto de vista empírico, sem o qual - eu The garanto - meu pequeno livro não tem sentido algum. Do ponto de vista filosófico, sem considerar sua premissa psicológica, é uma pura imbecilidade; do ponto de vista teológico, é nada mais do que crassa blasfêmia; e, do ponto de vista do senso comum racionalista, é um monte de fantasmagorias ilógicas e cretinas. Entretanto, a psicologia tem suas próprias proposições e suas próprias hipóteses de trabalho, baseadas na observação dos fatos, isto é (em nosso caso), a reprodução espontânea de estruturas arquetípicas que aparecem nos sonhos e também nas psicoses. Não se conhecendo esses fatos, fica difícil entender o que significa "realidade psíquica" e "autonomia psíquica". Concordo com o senhor que minhas afirmações (em "Antwort auf Hiob") são chocantes, mas, não mais e até bem menos, do que as manifestações da natureza demoníaca de Javé no Antigo Testamento (Jung para G. A. van den Bergh von Eysinga, 13 fevereiro de 1954, Letters, vol. 2:151-154).

Depois de um longo período de gestação ${ }^{12}$, Jung concebeu "Answer to Job"13 na primavera de 1951, aos 75 anos, logo após "Aion"14, seu irmão mais velho, ter sido publicado. Em muitas de suas cartas, Jung expressou a urgência física e a turbulência emocional das dores de parto das quais o livro veio à luz: foi "durante a febre de uma enfermidade" (Jung para $\mathrm{H}$.

\footnotetext{
${ }^{12}$ Shamdasani assinalou que a teologia articulada pela primeira vez em "Red Book", de Jung, encontrou sua "expressão e elaboração definitivas" em "Answer to Job" (Shamdasani 2010:ix).

${ }^{13}$ Michael Fordham indicou que, após "Moses and Monotheism" (1939) de Freud, "Answer to Job" é o mais importante trabalho publicado sobre a Bíblia, tratando das implicações religiosas da psicologia (Fordham $1955: 271-73)$.

14"Aion" é um dos livros mais complexos de Jung. O título refere-se a um ciclo de dois mil anos e à concepção astrológica do mês platônico. O éon cristão coincidiu com o signo de Peixes e, agora, dois mil anos depois, está prestes a entrar no de Aquário. Neste livro, Jung explorou as transformações históricas do cristianismo, incluindo a figura simbólica do antagonismo Cristo-Anticristo, e abordou de maneira especial como a doutrina cristã da privatio boni não lidou suficientemente com o problema do mal.
} 
Corbin, 4 de maio de 1953, "Letters", vol. 2:116) onde "fui atacado por meu fígado e tive que ficar de cama e escrever Jó" (Jung para H. Württemberg, 30 de agosto de 1951, "Letters", vol. 2:21); para sua secretária, Aniela Jaffé, descreveu o processo como tendo "aportado a grande baleia" e que isso, no entanto, ainda continuava a "ribombar um pouco, como um terremoto" (Jung para A. Jaffé, 29 de maio de 1951, "Letters", vol. 2:17-18). Alguns meses depois, com uma certa distância, resumiu toda a experiência para ela: "se há algo como o espírito agarrar alguém pela nuca, foi assim que esse livro se materializou" (Jung para A. Jaffé, 18 de julho de 1951, "Letters", vol. 2:20). Deirdre Bair relatou que Jung levou três meses para revisar o texto original e que escreveu até chegar à exaustão (Bair 2003:528). Shamdasani notou que nem o manuscrito original, nem a cópia datilografada revista encontram-se entre seus papéis no Swiss Federal Institute for Technology (ETH) (Shamdasani 2012:210). Jolande Jacobi, uma das colaboradoras de Jung, descreveu-o como 'taciturno, de maneira rude e primitiva, como um camponês [...] furioso o tempo todo" e seu comportamento era "como uma mulher dando à luz uma criança", ou como um homem "que se solta como uma criança malcriada" (Jacobi, em Bair 2003:528). Para Marie-Louise von Franz, Jung afirmou que gostaria de ter sido capaz de reescrever todos os seus livros, exceto esse -- com ele, estava completamente satisfeito (von Franz 1998:161).

"Answer to Job", de Jung, é um livro curto - apenas 108 páginas - mas, mesmo assim, foi altamente controverso e provocativo e conseguiu atrair uma pesada crítica em vários níveis. No prefácio, Jung escreveu que durante muitos anos hesitou em dar uma resposta mais completa às numerosas questões feitas por pacientes do mundo todo do que aquela que havia dado em "Aion", devido à tempestade que iria provocar (Jung 1952, ATJ, CW1 1, "Prefatory Note"). Aniela Jaffé assinalou que se Jung tivesse usado literatura profana ou material de pacientes para demonstrar a ambivalência da Imago Dei, talvez não tivesse ultrajado tanto seus leitores (Jaffé 1975:101)15. "Answer to Job" é o único comentário extenso de Jung sobre um texto bíblico ${ }^{16}$. Nele, discute o livro de "Jó", a "Epístola de São João", o "Apocalipse", o livro apócrifo de Enoque (cerca de 100 a. C.), a "sabedoria" (do grego "Sophia") da Bíblia hebraica e, finalmente, o dogma da Assunção da Virgem Maria (1 de novembro de 1950). Está fora do escopo deste trabalho abordar todos esses temas, assim, a próxima parte concentra-se no relato de Jung sobre as consequências do engajamento de Jó com um Deus que pode ser experimentado psicologicamente tanto como mal quanto como bem e o que isso significa para o homem moderno.

\footnotetext{
${ }^{15}$ Uma lista das primeiras respostas públicas a "Antwort auf Hiob" pode ser encontrada em Bishop (2002:185, n 1 13). Para um estudo judaico e uma crítica de "Answer to Job" de Jung, confira "Job: réponse à Jung", de Lévy-Valensi. Para uma perspectiva judaica sobre o problema psicológico do cristianismo ariano de Jung na interpretação do livro de "Jó", confira Corey: "For the Sake of God: a Reply to Jung". Corey também mostrou que a dependência de Jung das traduções cristãs da Bíblia e sua ignorância da escritura "oral", que complementa e amplifica a Bíblia "escrita", distorceu sua compreensão de Jó. Explicou ele: "Jó é, como descreve o Talmud, 'uma parábola' do destino redentor de Israel, escrito de acordo com a Escritura Oral pelo próprio Moisés à época da Revelação no Sinai" (Corey 1990:34).

${ }^{16} \mathrm{Jung}$ interpretou a tradição cristã em dois ensaios que foram primeiramente publicados no "Eranos-Jahrbuch 1940-41": "A Psychological Approach to the Dogma of the Trinity" e "Transformation Symbolism in the Mass". Seu ponto de vista amadurecido sobre a psicologia da religião foi aprofundado em "Aion" (1951) e finalmente em "Answer to Job" (1952).
} 
As reflexões psicológicas de Jung em "Answer to Job", sem dúvida, "prestaram homenagem ao espírito do protestantismo"17, o qual, argumentava, tinha "a grande tarefa de reinterpretar todas as tradições cristãs" (Jung 1952, ATJ, CW1 1: §§752-755). A despeito dos problemas da abordagem psicológico-crítica de Jung, seu tratamento das escrituras encontrou um lugar na interpretação bíblica ${ }^{18}$. Alguns especialistas externaram sua opinião sobre o estilo de Jung. O teólogo Kenneth Lambert assinalou logo de início que a posição de Jung faz uma mediação entre a exegese católica e a hermenêutica protestante (Lambert 1955:106-107). Jung previamente reconhece que sua posição parte de um cristianismo positivo, "que é tanto católico quanto protestante [...] e tenta estabelecer fatos nos quais os dois lados podem se unir" e complementa, dizendo: "esta é também a razão pela qual recebo pontapés dos dois lados" (Jung, "Letters", vol. 2:348-9). O professor de teologia James Heisig chamou a obra de "psicoteologia" e considerou que o motivo sutil de Jung em "Answer to Job" foi oferecer "uma alternativa ao ateísmo e à submissão piedosa", a despeito da "distorção exegética e da lógica dúbia de sua argumentação" (Heisig 1973:231; Heisig 1979:82, 88). O teólogo protestante Karl Barth argumentou que "Answer to Job" foi um "arrebatador documento humano" para o psicólogo; porém, como um trabalho de interpretação bíblica, a obra de Jung é "inaproveitável" (Barth, em Heisig 1979:182, n61; Bishop 2002:46). O analista junguiano Murray Stein argumentou que a abordagem de Jung é uma combinação de "hermenêutica e homilética", e um Auseinandersetzung com o Deus bíblico ${ }^{19}$. No final das contas, um Jung incontido apresentou sua causa diante de Deus, ao mesmo tempo em que tentou compreender e explicar a "grande imperfeição da Imago Dei ocidental" para seus leitores (Jung "Letters", vol. 2:434). A Imago Dei é um conceito central na psicologia da religião de Jung e é vista como uma expressão simbólica de uma imagem interna que transcende a compreensão consciente; é uma imagem de Deus e não como Ele é em si mesmo. Jung a descreve como: "um engrama ou impressão que, desde o início dos tempos, tem sido a expressão coletiva das mais poderosas e esmagadoras influências exercidas sobre a mente consciente pelas concentrações inconscientes da libido" (Jung 1921, CW6: $\S 412)^{20}$.

Para compreender o que Jung propõe em "Answer to Job", é necessário ter em mente alguns importantes pontos de partida em seu quadro de referência interpretativo:

1. Jung sustenta um ponto de vista subjetivo kantiano, no qual todo o conhecimento é mediado e que afirma que podemos perceber Deus apenas

\footnotetext{
${ }^{17}$ Jung considerava-se um protestante de esquerda e descrevia-se como: 'Definitivamente, estou dentro do cristianismo e, na medida em que consigo julgar-me, na linha direta do desenvolvimento histórico [...] Se a Reforma é uma heresia, certamente também sou um herético" (Jung "Letters", vol. 2:334).

${ }^{18} \mathrm{O}$ falecido Wayne Rollins, professor emérito de estudos bíblicos em Massachusetts, criou um novo modelo crítico para esses estudos e uma nova abordagem das escrituras nos anos 1960. Refletiu extensamente sobre a dinâmica da crítica bíblica psicológica e incorporou modelos desenvolvidos na psicologia profunda, dando ênfase especial aos insights de Jung sobre o valor de uma abordagem psicológica das escrituras no que se refere a símbolos bíblicos. Chamou essa perspectiva de "crítica bíblica psicológica". Para mais informações, ver Rollins, (1983; 1999). Outros importantes estudiosos são: Miller (1995) e Kille (2001). Clodagh Weldon, professor de teologia e autor de "Fr. Victor White OP: The Story of Jung's White Raven" (2007), dá cursos de "Answer to Job", de Jung, para alunos de bacharelado em seu curso de estudos bíblicos no Departamento de Teologia da Dominican University, em Illinois (Estados Unidos) (Weldon 2011:115-125).

${ }^{19}$ Uma palavra que significa, grosso modo, "um encontro diferenciador ou esclarecedor", com uma ideia ou uma pessoa; é usada mais comumente no léxico junguiano como "coming to terms with" (Bishop 2002:93; Stein 2007:313; Schlamm 2008:110).

${ }^{20}$ Ver J. Heisig (1979), "Imago Dei: A Study of C. G. Jung's Psychology of Religion".
} 
dentro dos limites de nossa própria psique ${ }^{21}$. A definição básica de Jung para Deus é:

Faço meus pacientes compreenderem que todas as coisas que thes acontecem contra sua vontade são uma força superior. Podem chamá-la de Deus ou de diabo e para mim tanto faz, desde que percebam que é uma força superior. Deus nada mais é do que essa força superior em nossa vida (Jung, em McGuire 1977:250).

Sua análise psicológica lida principalmente com a imagem de Deus observada em sua própria psique e na psique de seus pacientes e ele recusa-se a aceitar qualquer tipo de conhecimento fora da moldura psicológica. Reforçando sua posição como um empirista ${ }^{22}$, esclarece:

Posso confirmar e provar a interrelação da Imago Dei com as outras partes da psique, mas não posso ir além sem cometer o erro de uma asserção metafísica, o que está muito além do meu objetivo. Não sou um teólogo e nada tenho a dizer sobre a natureza de Deus (Jung para White, 5 de outubro de 1945, Lammers 2007a:9).

2. Jung concebia a psique como existindo por direito próprio, um mundo fenomênico em si mesmo. Sua posição psicológica reverteu a sequência causal racionalista, como ele explica: "em vez de derivar essas figuras de nossas condições psíquicas, [nós] precisamos derivar nossas condições psíquicas dessas figuras" (Jung 1942, CW13: §299; também Jung 1931/1933, CW8: §§649-688). As imagens psíquicas são tanto uma linguagem como uma dimensão da experiência interior, embora não separadas do mundo externo. Consequentemente, a imagem mítica de Javé é uma representação de sua realidade na psique.

3. Como psiquiatra, Jung valorizava o significado psicológico do simbolismo da narrativa bíblica e estava interessado em como ele podia ser traduzido na vida do indivíduo, uma vez que, para ele, "os mitos de natureza religiosa podem ser interpretados como um tipo de terapia mental para os sofrimentos e ansiedades da humanidade em geral" (Jung 1964:79). Interpretou o livro de "Jó" como um "dos marcos milenários que assinalam a longa caminhada da evolução de um drama divino" (Jung 1952, ATJ, CW 11: §560). Para ele, Jó "nada mais é do que a ocasião externa para um processo interior da dialética intradivina" (Jung 1952, ATJ, CW 11: §587). Seria possível ler a narrativa de Jung como um produto de imaginação ativa com as figuras

\footnotetext{
${ }^{21}$ Para mais informações sobre o background filosófico kantiano de Jung, ver Nagy (1991), "Philosophical Issues in the Psychology of C. G. Jung". Para uma crítica ao uso inadequado de Kant por Jung, ver Brooks (2011), "Un-thought out metaphysics in analytical psychology: a critique of Jung epistemological basis for psychic reality".

${ }^{22} \mathrm{O}$ estilo do empirismo de Jung foi muito criticado devido à impossibilidade de verificação e de refutabilidade científica da sua abordagem. O pragmatismo de Jung testa a verdade das coisas por meio da observação de seus efeitos. Sua lógica baseia-se no fato de que é difícil contestar um mito, um sonho ou um elefante; esses fenômenos podem ter uma realidade psicológica independentemente de coerência lógica, ver Lammers 1994:121.
} 
bíblicas, isto é, uma representação do choque entre a consciência do homem (Jó) e o encontro com o inconsciente desconhecido (Javé) (Schlamm 2008: 109-121) 23 .

4. Jung tinha a convicção de que sua psicologia analítica poderia contribuir para um processo de evolução religiosa, ao introduzir um novo mito no Ocidente (Dourley 2007:285). Por esse motivo, achava que era sua tarefa corrigir e complementar a transformação histórica da Imago Dei: "[M]inha obra lida principalmente com a transformação da doutrina cristã na era cristã" (Jung, "Letters", vol. 2:510f). Ann Lammers, que escreveu sua tese de doutorado sobre a relação Jung-White e foi a editora de "The Jung-White Letters" (2007), sugere que Jung "operava tanto como demolidor como construtor, demolindo partes da ordem existente porque queria reconstruí-la" (Lammers 1994:155). Em uma carta a Victor White, em 1953, Jung usou a seguinte metáfora para esclarecer o tipo de arquitetura que tinha em mente: "Ninguém é tão tolo a ponto de demolir as fundações quando está acrescentando um andar superior em sua casa; e, como realmente poderá construí-la, caso as fundações não sejam feitas da maneira correta?" (Jung, em Lammers 2007a:222).

Tendo agora estabelecido alguns dos pressupostos metodológicos de Jung, podemos, talvez, começar a apreciar o significado que extraiu das imagens incluídas no livro de "Jó", considerando que acreditava que elas apontavam para um desenvolvimento para além do cristianismo e continham uma nova dispensação para o homem moderno (Edinger 1992a:59. 60).

Em sua inflamada análise para o livro de "Jó", Jung faz um apelo para que o leitor o acompanhe em sua intensa confrontação com Javé. Além disso, tratando da questão crucial: "de onde vem o mal?", Jung parece estar articulando várias "respostas": a resposta de Javé a Jó, sua própria resposta para pacientes judeus e não judeus diante da guerra e, por fim, e não menos importante, sua resposta totalmente pessoal e sua poderosa discussão com Victor White (Confira Dourley 2007; Stein (2007a). Tanto o conteúdo como a intenção das reflexões psicológicas de Jung eram de um foco de luz sobre a ambivalência da imagem judaico-cristã de Deus. A essência de sua interpretação do encontro de Jó com a natureza paradoxal de Deus é a seguinte:

Javé está envolvido de maneira pessoal com o sofrimento humano, por causa de seu relacionamento com Satanás (ATJ, CW1 1: §616). Ele não tem consciência de sua brutalidade e insensibilidade no que se refere a todo o sofrimento que infligiv, apesar de ser onisciente. A submissão de Jó não se dá porque a justiça de Deus é um mistério incompreensível em termos humanos, mas, em vez disso, é uma crítica legítima de Sua injustiça (ATJ, CW1 1: §603). A resposta de Javé vinda de um redemoinho não é realmente uma resposta; Ele Se mostrou como uma força da natureza, comportando-se exatamente como um dos crocodilos ou como os Leviatãs que havia criado (ATJ, CW1 1: $\S \S 599,600)$. É culpa de Javé o mau uso do poder e Sua crueldade, ao trair Jó. Jó tem certeza de que não pecou e também tem certeza de que há um outro lado de Deus para o qual apela, na esperança de encontrar um "advogado" em Deus contra o próprio Deus (ATJ, CW1 1: §567). Ao manter-se firme defendendo sua posição sem

\footnotetext{
${ }^{23} \mathrm{~A}$ respeito de imaginação ativa, confira Jung, RB 2009:209; Id. 1954, CW14: §706; Id. 1916, CW8: §§ 131-193; von Franz, 1997:163-168; Hannah 2001:16-21; Hull 1971:115-120.
} 
pecado, Jó foi capaz de ver que a dupla natureza de Deus manifestou-se, expondo tanto Seu lado luminoso como Seu lado tenebroso (ATJ, CW1 1: $\S \S 584,608)$. Essa constatação produz uma transformação radical: é Javé que é infiel, não Jó (ATJ, CW1 1: §616). Esse preciso ato de consciência eleva Jó - um ser humano mortal é elevado, por meio de seu comportamento moral "acima dos astros"; a criatura sobrepujou seu Criador (ATJ, CW1 1 : $\S \S 595,640$ ).

Javé sofreu uma derrota moral ao falhar em corromper Jó (ATJ, CW 1 1: §617). Tendo Deus cometido um erro contra o homem, começa a tomar forma uma compensação na psique para o sofrimento imerecido de Jó: Deus quer renovar-se e tornar-se humano (ATJ, CW1 1: $\S \S 624,631$, 640). Entretanto, ocorre uma separação decisiva na Imago Dei - Seu lado sombrio é cindido, porque Javé identifica-se apenas com Seu aspecto luminoso ao encarnar-se em Cristo na terra. Embora Cristo tenha se tornado homem, Sua natureza é mais divina do que humana; ele não nasceu de um pai humano e sua mãe era virgem (ATJ, CW1 1: §626). Foi apenas quando Cristo bradou na cruz: "Meu Deus! Meu Deus! Por que me abandonaste?" que Deus experimentou o que significa ser mortal (ATJ, CW11: §647). Nessa posição, sofrendo e experimentando o mal na carne, Deus finalmente dá uma resposta a Jó (ATJ, CW1 1: §647). Javé não poupou Seu filho; pelo contrário, Ele esperou um sacrifício humano e, da mesma maneira, o ser humano agora encontra-se onde Jó e Cristo estiveram - abandonado e com a natureza paradoxal de Deus pesando fortemente sobre ele. Devido à incompleta encarnação de Javé em Cristo, que encarnou apenas Seu lado bom, uma nova tarefa é colocada para a humanidade: a resolução da antinomia divina precisa ocorrer no homem (ATJ, CW1 1: §§655, 657, 690). A redenção não ocorre por meio da fé em Cristo, que nos salvou vicariamente, mas na conscientização da parceria inescapável e na responsabilidade compartilhada do divino e do humano tanto para o bem como para o mal no mundo (ATJ, CW1 1: $\S \S 659,693)^{24}$.

papel fundamental de Jó serviu para ampliar o mito junguiano da encarnação continuada como um símbolo para o desenvolvimento psicológico. Assim, ao rejeitar e rever a submissão do homem a um Deus amoroso, Jung, por um lado, acrescentou outro nível de compreensão à experiência do sofrimento e, por outro, questionou os ensinamentos da igreja, de que a encarnação foi um evento histórico único. Argumentou que ela não cessou com a Ascensão, mas continuou por meio do Espírito Santo no homem. Chamou esse processo de "cristificação de muitos" 25 , onde Cristo deve ser encarado como um padrão a ocorrer em cada homem, e Deus deve encarnar no ser humano comum. Como era de se esperar, a insistência de Jung em colocar o bem e o mal como parte da essência do Próprio Criador e sua abordagem de uma nova dispensação psicológica para o homem moderno foram tomadas como uma ofensa contra séculos de reflexão teológica.

\section{Resposta a Jung}

[...] De maneira geral, ["Answer to Job"] não pode ser lido, pois Jung deliberadamente lê as Escrituras usando óculos altamente

\footnotetext{
${ }^{24}$ Para uma interpretação psicológica mais detalhada de "Answer to Job", de Jung, ver Edinger 1992a: 5990; Evans 1954:5-26; Stein 2003:1-18.

${ }^{25}$ Jung usou esse termo pela primeira vez no último parágrafo de "Answer to Job", mas essa ideia tem raiz no conceito de sua interpretação da imitatio Christi no "Red Book", elaborou-o então nas "Collected Works", a partir de sua palestra em Eranos "On the Psychology of the Idea of the Trinity", em 1940. Jung 1952, ATJ, CW1 1: §758; Id. 2009, RB:292-6; Heisig 1979:184, n88.
} 
distorcidos. Embora não esteja escrevendo sobre Deus, mas sobre a Imago Dei, não está escrevendo diretamente nem mesmo sobre as imagens de Deus de Jó, mas sim sobre suas próprias imagens sobre as imagens de Jó [...] Mesmo um cristão instruído pode esperar uma explosão quando um adulto, cujo desenvolvimento religioso fixou-se no nível do jardim da infância da moralidade burguesa [...], confronta-se com as realidades da vida, com os modos de Deus na Bíblia e nos acontecimentos contemporâneos. É compreensível que ele sinta uma grande afinidade com o Jó desiludido e torturado [...] A violência da ab-reação é compreensível [...] seu ressentimento é pouco adulto [...] a única reação é a de uma criança mimada (White, em Lammers 2007a:353-354).

Esse foi o dobre de finados do longo relacionamento entre Victor White e Jung. White tinha sido o mais importante colaborador teológico de Jung por mais de 15 anos e, em pouco tempo, tornara-se um amigo pessoal muito próximo. Menos de um ano após a primeira correspondência entre eles, White fez a primeira de 10 visitas a Bollingen, em agosto de 1946; a última visita foi em julho de 1952. O último encontro deles foi em junho de 1958, mas, dessa vez, em Küsnacht. Jung fez de White um membro integrante do círculo intelectual junguiano; White foi convidado a dar palestras nas Conferências de Eranos e, em 1947, também foi convidado para ser um dos membros fundadores do Instituto C. G. Jung, em Zurique. Adrian Cunningham, professor de estudos teligiosos e especialista em Victor White, assinalou em uma entrevista que "Victor White foi uma das poucas, possivelmente a única pessoa do círculo íntimo que realmente enfrentou o velho homem [Jung], e com ele travou uma luta durante anos, até que ambos ficaram exaustos com a contenda" (Arraj 2015).

Jung expressou pesar pela morte de White: "Como partilhei de sua vida e desenvolvimento interior de modo tão sincero, sua morte tornou-se outra experiência trágica para mim" (Jung, em Lammers 2007a:303). A trajetória do relacionamento pessoal de Jung e White reflete-se por toda a discussão que tiveram sobre a relação entre psicologia e religião em "The Jung-White Letters". As cartas são apresentadas de maneira autêntica em um diálogo "coeso", sem acréscimos editoriais. Ambos eram especialistas em seus próprios campos e nos densos anos do pós-guerra esperavam criar uma aliança para promover a saúde espiritual na modernidade e "transformar o Ocidente cristão" (Lammers 2007b:253). Entretanto, na medida em que o diálogo junguiano-cristão progredia, o entusiasmo de ambos virou rejeição e a colaboração tornou-se controvérsia, até chegar a um ponto sem retorno. A visão de ambos sobre Deus e o mal não pôde ser reconciliada e as tensões presentes desde o início tornaram-se impossíveis de serem superadas, após a publicação da tradução em inglês da obra, em 1954. Lammers classificou as desavenças entre White e Jung em três níveis: doutrinal, hermenêutico e epistemológico (Lammers 1994:18-24).

Victor White (1902-1960) foi um católico convertido e professor de teologia dogmática na Escola Dominicana Blackfriars, em Oxford (Reino Unido). Em virtude de uma crise de fé, abriuse para o pensamento de Jung, começando a fazer análise em Londres, em 1939. White assim descreveu essa crise de fé:

Sou por profissão um teólogo. Sou, porém, um teólogo a quem algo aconteceu. De repente, ou talvez não tão de repente, a teologia deixou de ter qualquer significado para mim [...] e assim fui forçado 
a me voltar para os psicólogos [...] Tive de fato um palpite de que o método e a abordagem de Jung poderiam ter algo que falasse à minha condição (White, em Weldon 2007:16).

White também participou de um grupo de estudos com alguns dos primeiros discípulos de Jung, nele introduzido por seu analista, o antropólogo John Layard (1891-1974), que fez sua formação com o próprio Jung (Lammers 2007b: 255). White vinha estudando a obra de Jung há cinco anos quando, encorajado por Gerhard Adler (1904-1988) ${ }^{26}$, escreveu para Jung pela primeira vez, logo após o fim da Segunda Guerra, em 1945, enviando alguns ensaios nos quais estabelecia uma ligação entre as doutrinas da igreja e a psicologia junguiana: "The Frontiers of Theology and Psychology" (1942), "St. Thomas Aquinas and Jung's Psychology" (1944), "Psychotherapy and Ethics" (1945) e, por último, um "Postscript", que resenhava um livro de um psicoterapeuta freudiano sobre as implicações éticas da psicoterapia (Lammers 1994:35). Jung tinha acabado de comemorar seu aniversário de 70 anos e viu a chegada de White como uma contribuição inestimável. Jung assim a descreveu: "Desculpe-me pelo trocadilho irreverente: você é para mim um corvo branco (white raven), na medida em que é o único teólogo que conheço que realmente compreendeu algo do que significa o problema da psicologia em nosso mundo atual" (Jung para White, em Lammers 2007a:6). Ele estivera esperando durante anos por um parceiro teológico com quem pudesse "discutir em pé de igualdade questões de importância vital" e que pudesse ajudá-lo a refinar sua interpretação do catolicismo (Jung, Letters, vol. 2:450n; Lammers 1994:36), o que Jung valorizava muitíssimo, uma vez que, para ele, o catolicismo era um "tesouro de sabedoria patrística" (Jung, em Lammers 2007a:5). Ann Lammers chamou atenção para o fato de que, embora White fosse 27 anos mais moço do que Jung, não era, de forma alguma, o parceiro júnior nesse encontro ${ }^{27}$. Ele era capaz de ler francês, alemão, espanhol, italiano e latim "facilmente"; por volta de 1940, White era conhecido como um tomista de primeira grandeza: fazia parte de um grupo de intelectuais dominicanos que trabalhavam em uma nova tradução anotada da "Summa Theologiae"28. Em 1954, recebeu o título de mestre em Teologia Sacra (STM), o mais alto grau teológico concedido desde a época medieval, em "sinal de mérito excepcional como um intelectual e professor de teologia" (Lammers 2007a:16, n50). White logo aumentou seu conhecimento e tornou-se, também, versado em psicologia analítica; era de opinião que a religião e a psicologia "partilhavam um território comum e numerosas preocupações [...] e esse território comum é o que a religião denomina alma humana e o que a psicologia chama de psique humana" (White, em Cunnings, "Victor White, a Memoir", em Lammers 2007a:321). Em seu encontro com a psicologia junguiana, White esperava fazer uma síntese e construir uma ponte teórica entre os dois sistemas de pensamento, onde o tomismo suplementasse e completasse a psicologia analítica com a verdade cristã e o insight psicológico fosse usado como uma ferramenta pedagógica para a igreja e seu clero (Lammers 1994:55, 71; Stein 2011:601).

\footnotetext{
${ }^{26}$ Gerhard Adler, de ascendência judaico-alemã, foi o editor da tradução inglesa das "Collected Works", de Jung. Também foi fundador da Associação de Analistas Junguianos e cofundador da Sociedade de Psicologia Analítica, bem como membro fundador da Associação Internacional de Psicologia Analítica.

${ }^{27}$ Para um relato de como a relação de Jung e White foi uma tentativa de continuar o debate teológico com seu pai e para um paralelo entre a relação Freud-Jung e com a de Jung-White, ver Stein 2007:303-14.

${ }^{28}$ Obra que imortalizou São Tomás de Aquino (1225-1274), a "Summa Theologiae" é um manual de doutrina cristã e um livro didático para o estudo da teologia. Tem sido usada por mais de 700 anos. São Tomás sistematizou a teologia, estabelecendo as relações entre fé e razão. Ele é considerado o "Aristóteles cristão", por combinar a filosofia aristotélica com a ortodoxia eclesiástica.
} 
Atraído pelo elemento religioso do sistema de Jung, White realmente acreditava que poderia suplementar a deficiência metafísica deste sistema (Weldon 2007:20, 22). Escreveu vários artigos e resenhas sobre a psicologia junguiana, esclarecendo e articulando tanto as diferenças como os pontos de contato entre a teologia e psicologia ${ }^{29}$. Um importante terreno comum que partilhavam era uma preocupação de longo alcance com o sofrimento do ser humano, uma vez que as duas disciplinas aceitam a responsabilidade prática pela cura animarum (Jung, "Letters", vol. 2:553). Outro ponto que colocou o clérigo e o psicólogo "ombro a ombro" foi a questão do bem e do mal (Jung 1932, CW11: §504). Infelizmente, a ideia de uma coordenação teórica compatível fracassou tragicamente, precisamente na medida em que tentavam educar-se um ao outro sobre seus pontos de vista opostos em relação à natureza do mal.

Antes, porém, de passar à próxima seção, será útil contextualizar o pano de fundo da disputa entre eles, uma vez que, na retaguarda, havia importantes pontos de partida contrastantes. O primeiro deles era a barreira teórica de dois campos de associação filosóficos totalmente diferentes: White era um lógico tradicional, seu pensamento baseava-se no intelectualismo aristotélico e no pensamento filosófico de Santo Agostinho e Tomás de Aquino. Em contrapartida, o pensamento de Jung fora moldado pelo subjetivismo kantiano, pelo protestantismo pós-Schleiermacher e pelo pragmatismo de William James (Lammers 1994:1617, 114-132). Não é de admirar que as discrepâncias filosóficas da autoridade do dogma, baseado na tradição, versus a autoridade do indivíduo, baseada na experiência, tivessem se tornado um "obstáculo intransponível" entre eles.

Em segundo lugar, White estava sujeito a autoridade eclesiástica, em virtude de seu voto de obediência. Jung, por sua vez, estava em situação privilegiada, com alto grau de autonomia profissional, o que lhe permitia ser independente, 'pôr em risco sua própria existência' (Jung, em Lammers 2007a:264). É especialmente importante enfatizar esse ponto, uma vez que a associação de White com Jung trouxe para White sérias consequências como um intelectual tomista. O cenário político da cultura católica da época de White era opressivo, com a neoescolástica e o reaparecimento moderno de São Tomás, que ocorreu na metade do século 19 em reação ao conhecimento secular. Esse movimento conservador endossou um retorno à teologia escolástica do século 13 como forma de proteção contra a heresia do "modernismo" e, além disso, para condenar os que contradiziam o magisterium ${ }^{30}$. A vigilância episcopal, o Imprimatur, dando permissão para publicações, a condenação de títulos censurados, incluindoos no Index Papal, o juramento antimodernista e a excomunhão eram algumas das drásticas

\footnotetext{
${ }^{29}$ Os principais escritos de White sobre a psicologia junguiana são: "The Frontiers of Theology and Psychology", palestra 19 no "Guild of Pastoral Psychology" (1942); "The Analyst and the Confessor", em "The Commonweal: A Review of Religion, Politics, and Culture" (1948); "Eranos: 1947/1948", em "Dominican Studies" (1949); "God and the Unconscious" (1953); "Jung on Job", em "Blackfriars" (1955); "God and the Unknown and other Essays" (1956); críticas literárias de "The Collected Works of C. G. Jung": Volume 1 and Volume 5, em "Blackfriars" (1957); "Critical Notices: Psychology and Religion, by C. G. Jung", no "Journal of Analytical Psychology" (1959); "Soul and Psyche: An Enquiry into the Relationship of Psychotherapy and Religion" (1960).

${ }^{30} \mathrm{~A}$ guerra contra o modernismo foi uma batalha institucional dentro da Igreja Católica, provocada pelo medo de uma mudança histórica "infectada pelo espírito kantiano", que poderia pôr em risco a fé e a moralidade. Em 1864, o Papa Pio IX publicou o "Syllabus" de erros contra a fé. No século 20, o Papa Pio X caracterizou o modernismo como a 'síntese de todas as heresias", condenou o saber católico de tendências modernistas e ordenou todo o clero a asseverar compulsoriamente sua lealdade ao juramento antimodernista. Ver: F. S. Fiorenza, J. C. Livingston (1971), "Modern Christian Thought", Vols. I, II.
} 
medidas usadas para impor obediência à autoridade eclesiástica ${ }^{31}$. White, de sua parte, estava entre os teólogos que tentaram criar uma teologia mais vital; ele era um "tomista moderno", que se identificava com São Tomás, não como um aliado contra a modernidade, mas como um modelo para integrar diferentes compreensões da verdade. $\bigcirc$ próprio São Tomás encontrou verdade também nos filósofos muçulmanos Avicena e Averroes, no Rabino judeu Maimônides e no filósofo pagão Aristóteles (cit. em Weldon 2010:178). Foi essa predisposição que tornou White susceptível não apenas à psicologia de Jung, mas também aos conflitos teológicos dentro de sua Ordem e às imposições da Igreja Romana.

\section{A arena da disputa: a visão escolástica e junguiana sobre o problema do mal}

A doutrina do mal como uma privação do bem parece ter sido proposta pela primeira vez por Santo Agostinho no século 5, especialmente em sua defesa do monoteísmo contra o dualismo maniqueísta, que encarava bem e mal como princípios mutuamente excludentes; as raízes filosóficas dessa ideia, entretanto, remontam a Aristóteles ${ }^{32}$. Foi São Tomás, porém, quem mais tarde desenvolveu e sistematizou a doutrina da privatio boni de maneira mais completa no século 13 (Aquinas 1993:284-289; Davies 2001:55-119). Essa definição baseia-se na convicção de que Deus, como o summum bonum, é um Deus supremamente bom, que criou todas as coisas, mas não o mal. O mal não tem status ontológico, não é um ser criado e não tem fonte de poder; pode ser entendido como uma ausência, uma distorção ou até como parasita do bem. A negação da substancialidade do mal e sua relação subordinada ao bem ainda é "amplamente mantida e ensinada na tradição católica" (Lammers 1994:289, n29). Ademais, em ambas as noções clássicas do mal como privação, sejam elas filosóficas, sejam teológicas, há um fenômeno de redução, e sua interpretação é totalmente negativa. Inversamente, conforme mencionado na parte anterior deste ensaio, para Jung o mal é um componente positivo da realidade e um contrário igual ao bem - sendo Cristo e Satanás os exemplos primordiais da cisão entre bem e mal e da contradição do mito cristão. White repetidamente tentou esclarecer a lógica tomista para Jung em cartas e trabalhos escritos sobre o tema: "Bem e mal, em abstrato, são de fato opostos, mas, ao refletirmos sobre isso, provam não ser dois contrários positivos äquivalente Gegensätze como Jung os chama - mas contraditórios" (White 1960:153). Podia concordar com Jung que eram opostos, mas não contrários equivalentes.

No início, White achou que a diferença era "sem importância e acadêmica", mas, na medida em que a discussão sobre essa questãos progredia, concluiu que ela "afetava seus julgamentos de valor de quase tudo" (White, em Lammers 2007a: 182). A Imago Dei ambivalente de Jung perturbava sua crença e a representação ortodoxa de um Deus bom e perfeito para além dos opostos de bem e mal, até que, em 1949, White pela primeira vez corrigiu publicamente a 'teologia inferior" de Jung, em sua palestra nas Conferências de Eranos "Über das Selbst":

Um estudo elementar (por exemplo) das seções de São Tomás na Prima Pars Sobre o Bem, Sobre a Bondade de Deus, Sobre o Mal, e

\footnotetext{
${ }^{31}$ Ver, por exemplo, http://w2.vatican.va/content/pius-x/en/encyclicals/documents/hf_px_enc_19070908_pascendi-dominici-gregis.html

${ }^{32} \mathrm{Em}$ "Metaphysics", Aristóteles argumentou que o bem é o princípio governante do universo; elencou vários tipos de privação, e o mal como uma privação do bem. Ver "Metaphysics", de Aristóteles, Livro IX. Para o ponto de vista de Santo Agostinho, ver "Confessions", de Agostinho, Livro III.
} 
Sobre a Causa do Mal, deveriam ser suficientes para dissipar os equívocos e dúvidas do doutor Jung e oferecer uma metafísica para explicar os fenômenos que o preocupam, de forma ao menos tão satisfatória quanto o dualismo quase-maniqueísta que ele propõe. Essas páginas algo confusas e desconcertantes podem ser descartadas como apenas mais uma incursão infeliz de um grande cientista fora de sua própria órbita [...] É realmente lamentável que, apoiando-se apenas nesse filosofar ingênuo, o mais fecundo movimento da psicologia contemporânea deva ser associado de modo irrelevante ao dualismo gnóstico (White 1949:399).

Isso acabou por ser um ponto de inflexão crucial da relação deles e um prenúncio de "uma tempestade a caminho" - o impasse sobre a natureza do mal tinha transbordado da correspondência privada para a arena pública: Jung tinha atacado de maneira mais vigorosa a definição metafísica do mal em sua palestra "Über das Selbst", que foi depois seguida pela resenha crítica de White; a palestra de Jung, posteriormente, tornou-se os capítulos quatro e cinco de "Aion:", em que ele responde à crítica de White em uma nota de rodapé:

Meu douto amigo Victor White O.P. [...] acredita poder ter detectado traços maniqueístas em mim [...] Além do mais, meu crítico poderia muito bem saber o quanto enfatizo a unidade do Self, esse arquétipo central, que constitui uma complexio oppositorum (conjunção de opostos) por excelência, e é por esse motivo que não me sinto absolutamente inclinado ao dualismo (Jung 1951, CW9ii: §112, n75).

A partir desse ponto, a correspondência entre eles ficou "presa em disputas linguísticas" sobre Deus e o mal na mais "obstinada forma de divergência" (White 1960:75). White continuou a propor distinções teóricas e conceituais, mas as bases de seus argumentos não foram suficientes para convencer Jung. Ainda eram amigos, mas, inevitavelmente, cada um deles tornou-se mais e mais crítico do outro. A seção seguinte aborda cronologicamente o curso da controvérsia entre eles, revelando o crescendo do processo, até a culminação em "Jung on Job" de White. Depois de seis anos, ambos estariam mortos, reconciliados como amigos no fim; mas, o mal permaneceu como uma disputa intelectual jamais resolvida.

Em março de 1952, White publicou uma série revisada de palestras e ensaios em seu livro "God and the Unconscious". Ainda fazendo um esforço para construir uma ponte, mas mesmo assim criticando Jung sem rodeios, White refletiu cuidadosamente:

Há motivos muito compreensíveis pelos quais os teólogos e os filósofos tiveram dificuldade de levar a obra de Jung a sério. Os obstáculos à compreensão são consideráveis e não devem ser minimizados [...] Ao encarar o mal como (aparentemente) tendo alguma existência positiva e realidade própria, Jung obviamente exige a admissão do mal não apenas no "self", a totalidade humana, mas também na própria Divindade [...], o que os cristãos ortodoxos devem considerar bastante inadmissível (White 1952:65, 75). 
Jung, que tinha escrito um prefácio para esse livro de White, continuou a abordar algumas das importantes diferenças entre a psicologia e a teologia e aproveitou a oportunidade para explicar sua crítica da doutrina da privatio boni mais uma vez: "Consequentemente, sintome à vontade para me servir do direito de crítica livre tão generosamente a mim oferecido pelo autor, e expor minha argumentação [sobre a privatio boni] perante o leitor" (Jung 1951, CW1 1:§456). Nesse ponto, a despeito de se recusar a concordar com Jung e de defender a doutrina clássica, White ainda considerava a possibilidade de alcançar algum acordo após a superação de "fortes resistências":

Jung tem nosso mais veemente apoio e simpatia ao deplorar a minimização do mal, o que leva à sua repressão, com resultados devastadores para as psiques individual e coletiva, mas não conseguimos encontrar evidências de que a concepção da privatio boni tenha contribuído para isso (White 1952:75-76, n1)

Dois meses mais tarde, na primavera de 1952, Jung enviou a White o manuscrito de "Antwort auf Hiob", e a primeira resposta de White foi muito positiva: "Um milhão de obrigados por 'Hiob' [...] Não consigo parar de lê-lo. É o livro mais comovente e empolgante que li em muitos anos". Então, na mesma carta, queixou-se: "Realmente gostaria que pudéssemos de alguma maneira resolver esse impasse sobre a privatio boni", e, no final, concluiu de maneira muito cordial: "Serei eternamente grato a você, não importa o que aconteça com essa dificuldade da privatio boni" (White, em Lammers 2007a:181-182). Conforme mostrado no exemplo da carta, o debate intelectual entre eles continuou, ao mesmo tempo em que compartilhavam profundos e contraditórios sentimentos e ansiedades entre amigos. Durante todo esse ano, a discussão a respeito do problema do mal cresceu, até atingir seu auge ${ }^{33}$.

Nos anos de 1953 e 1954, White foi de novo atormentado por dúvidas sobre se deveria ou não permanecer em sua Ordem e na lgreja e confidenciou a Jung:

[...] o Deus deles simplesmente não é mais o meu Deus: as minhas próprias vestes clericais tornaram-se uma farsa [...] Estou apenas indescritivelmente solitário e me dá algum alívio contar-lhe isso [...] Devo confessar que há momentos em que desejaria de todo coração nunca ter ouvido falar de sua psicologia (e de alguns de seus discípulos!); e ao mesmo tempo, tremo ao pensar o que teria acontecido se eu não o tivesse feito! (White, em Lammers 2007a:216-217).

A psicologia de Jung representava um paradoxo de atração-rejeição para White: quanto mais a compreendia, mais ela significava uma ameaça para sua fé e mais se tornava incompatível com sua teologia. Apoiado por Jung, White decidiu permanecer como dominicano e assinou o juramento antimodernista mais uma vez. Logo após, recebeu seu título de mestrado, um prérequisito para sua carreira conduzi-lo a Regent of Studies em Oxford. Esse era um cargo muito ambicionado por White, uma vez que iria ser responsável pelo currículo e treinamento de novas gerações de dominicanos e, mais importante ainda, passaria a ter "grande influência" em como

\footnotetext{
${ }^{33}$ Confira especialmente a correspondência entre eles em abril de 1952, 30 de junho de 1952 e 9 de julho de 1952. White também esteve em Bollingen por 10 dias, em julho de 1952, onde a discussão entre eles prosseguiu, citado em Lammers 2007a:293, n5.
} 
São Tomás seria ensinado em Blackfriars. Infelizmente, em virtude de sua vida professional ter ficado enredada em sua amizade com Jung, um novo neotomista conservador foi nomeado para o cargo em vez dele e White foi mandado por cinco meses para a Califórnia, "em exílio" ${ }^{34}$. Nunca mais lecionou em Oxford.

Enquanto isso, a polêmica em curso com Jung sobre o mal continuou na Califórnia e ambos começaram a antecipar as possíveis dificuldades que "Answer to Job" acarretaria. Em janeiro de 1955 White expressou:

Estou realmente aliviado que "Answer to Job" não tenha ainda aparecido nos EUA! [...] Naturalmente, já estou recebendo cartas perplexas e indignadas da Inglaterra, perguntando "Que diabos..." Isto me custa umas boas noites insones tentando escrever um artigo para explicar o que penso [...] Espero que você não considere o resultado (que pretendo enviar-lhe se e quando for publicado) muito devastador; e especialmente que você leve em consideração para quem ele é escrito (White, em Lammers 2007a:254).

Ao que Jung respondeu: "Sei que você terá algumas dificuldades quando o meu 'Answer to Job' se tornar público. Sinto muito" (Jung, em Lammers 2007a:256). Entretanto, nenhum dos dois poderia ter imaginado o quão profundamente o golpe iria repercutir e quão dolorosas seriam as consequências para ambos. Em março de 1955, White escreveu sua resenha "Jung on Job" para a revista "Blackfriars". Nela, publicamente acusou Jung de levar a interpretação pessoal das escrituras a um ponto extremo e, no que acabou sendo um ataque ad hominem, chamou o livro de "destrutivo e infantil", e acusou Jung de ser paranoide, questionando:

[...] estará ele, à maneira de seu próprio "Javé", ludibriado por algum trickster satânico, propositadamente torturando seus amigos e devotos? Ou está ele, mais racionalmente, de propósito testandoos, para ver até quando aguentam antes de admitirem a falibilidade de seu mestre - ou quantos, mais semelhantes a Jó, terão a coragem de apontar que o Imperador apareceu nu em público? (White 2007:352) ${ }^{35}$.

Algumas das razões por que White perdeu seu "controle retórico" foram apontadas por vários estudiosos (Lammers 1994, 2007a; Weldon 2007; Cunningham 2007, 1981). Em primeiro lugar, embora como sacerdote tivesse sido treinado a obedecer, não tinha aceitado completamente a humilhação de ter preterida sua nomeação como Regent pela sede em Roma. Em segundo lugar, ficou extremamente frustrado por, após ter passado 10 anos tentando traduzir a psicologia junguiana para teólogos, ter seus esforços impedidos; e, em terceiro lugar, ficou profundamente magoado por não mais ser apreciado como professor dentro da Ordem. Assim, a raiva sentida por White por ter sua carreira comprometida dentro da Ordem voltou-se, externamente, para Jung (Lammers 2007a:258-265; 1994:101-109; Weldon 2007:181-187; Rutte 2009:308-310). Contudo, White não foi consistente em seu ataque e antes de a resenha

${ }^{34}$ White saiu de Oxford em 16 de outubro de 1954 e foi para a St. Albert's Dominican House, em Oakland, Califórnia. Lammers especula que a força motriz por trás da decisão veio do próprio Provincial de White. Ver Lammers 2007a:247-248, n88, 89, 90, 91, 92; Id. 2007b:264-265; Weldon 2007:179-181.

${ }^{35} \mathrm{Em}$ 1959, White também criticou "Answer to Job" em sua resenha sobre "Psychology and Religion", de Jung, mas dessa vez de uma maneira mais equilibrada. 
ser publicada, escreveu a Jung pedindo perdão: "[...] há alguns trechos que agora preferiria ter guardado só para mim [...] e me penitencio de ter exposto minha crítica de maneira tão dura" (White, em Lammers 2007a:259-260). Duas semanas mais tarde, Jung respondeu a White:

Estou grato pelo fato de que sua reprimenda a mim dirigida e que seu julgamento - correto ou não - não me poupem, de modo que presumo que Deus dará ouvidos a uma voz mortal, como deu ouvidos a Jó, quando esse vermezinho torturado queixou-se de Sua natureza amoral paradoxal. Da mesma forma que Jó levantou sua voz, de modo que todos pudessem ouvi-lo, cheguei à conclusão de que é melhor arriscar minha pele e fazer o pior ou melhor para sacudir a inconsciência de meus contemporâneos. [...] em nossa época tudo está em jogo e não se deve dar importância ao pequeno transtorno que estou causando [...]. Hesitei e resisti por um longo tempo, até que tomei a decisão de dizer o que penso (Jung, em Lammers 2007a:261-262).

Jung então ofereceu a White uma leitura psicológica:

Sua crítica de minha motivação a respeito de "Jó" é certamente injusta, e você sabe disso. É a expressão de um tormento mental que você teve que sofrer nos EUA - e na Europa [...]. Tendo escolhido a vida de monge, você afastou-se do mundo e se expôs ao fogo eterno do outro. Em algum momento, paga-se o preço seja ao Homem, seja a Deus e, no final das contas, descobre-se que ambos exageraram no preço (Jung, em Lammers 2007a:263).

Nesse ponto, Jung mostrou que, em virtude de White estar "sendo alimentado por uma instituição por serviços recebidos", tinha que ter cautela quanto à maneira de se expressar. Um ponto importante que confirma esse fato foi dado por outro padre que foi expulso dos dominicanos, tendo então sido aconselhado por seu advogado de direito canônico: "Você deve lembrar-se que afrontar o Vaticano é como se colocar diante de um trem. Não dá para vencer; ninguém jamais o conseguiu" (Rutte 2009: 50). White permaneceu na Ordem e chegou à conclusão de que era impossível reconciliar a posição junguiana com a teologia tradicional. As ramificações das diferenças entre eles estavam enraizadas de maneira muito profunda e não havia compromisso possível: para White, a teologia era "a rainha das ciências"; dessa forma, tinha primazia sobre a psicologia e - Deus, não a psique - detinha a autoridade final (ver Weldon 2007:219).

A despeito de tudo isso, White desculpou-se por ter atacado Jung tão duramente: "Lamento profundamente, de fato, ter publicado aquele artigo sem qualquer consideração por seus sentimentos ou pelos meus próprios sentimentos por você" (White, em Lammers 2007a:268). Continuou, entretanto, a escrever cartas antagonistas e, em uma delas, incluiu uma lista de vários "Problemas Decorrentes da Publicação de Resposta a Jó":

"Answer to Job" deve, presumivelmente, ser lido não como um ensaio de teologia, metafísica ou exegese, mas sim como um livro de psicologia prática... Quais são, então, seu conteúdo e implicações psicológicas práticas? Em primeiro lugar e acima de 
tudo, parecem ser: Deus (não eu) é inconsciente, dividido em si mesmo, temperamental, caprichoso e sem propósito - mas, notavelmente, tanto mau como bom. O mal é um constituinte último e irredutível da realidade a ser aceito - não uma privação que pode ser suprimida pelo bem, ou a partir do qual o bem pode ser extraído. Meu "mal' não é mais responsabilidade minha. Tudo é "culpa de Deus" e posso e devo pôr toda a culpa nEle [...] a sombra pessoal é transferida para a esfera "divina", "coletiva", e lá deixada. Se essas não são as implicações psicológicas do livro, são as óbvias que de fato estão sendo extraídas e precisam, urgentemente, das correções do autor (White, em Lammers 2007a:268-272).

Assim, a despeito de expressar seu pesar pelo amigo e de, posteriormente, ter retirado várias passagens na versão editada de "Jung on Job", em seu livro "Soul and Psyche" (1960) (White 1960:233-240), a publicação da resenha de White foi um golpe que funcionou nos dois sentidos: ele separou-se definitivamente do quadro de referência de Jung e isso prejudicou a amizade deles para sempre:

Para mim, parece que nossos caminhos devem, pelo menos em certa medida, separar-se. Nunca esquecerei, e rogo a Deus que nunca perca, o que devo à sua obra \& nossa amizade [...] "Espero que você não ponha em dúvida minha amizade, o pensamento teimoso \& sem compaixão como ele às vezes se revela. $\bigcirc$ pobre Jó ao menos tinha amigos - mesmo obtusos" (White, em Lammers 2007a:273).

White continuou a escrever para Jung (três cartas, em 1955; uma, em 1956; e duas, em 1958), mas Jung não mais respondeu. Nesse período, Emma Jung foi diagnosticada com um câncer terminal ${ }^{36}$ e Jung, pesaroso e esgotado pela doença dela, pediu a White: "Por favor, deixe de lado a convencionalidade e não se sinta com qualquer obrigação [...] um telefonema convencional nada significa para mim e uma conversa direta pode ser dolorosa e não desejável" (Jung, em Lammers 2007a:266). O último esforço de White para esclarecer sua polêmica com Jung foi o ensaio "Kinds of Opposites", publicado em "Fetschrift", em 1955, para o aniversário de 80 anos de Jung, onde discutiu como São Tomás abordou a questão do bem e do mal e forneceu o vocabulário de sua principal diferença intelectual entre ele e Jung (Lammers 2007a:255-256, n10). Foi escrito algumas semanas após sua reação pública a "Answer to Job".

Após um afastamento de três anos, os dois homens se encontraram brevemente e pela última vez em 1958, em Küsnacht (Suíça). Em abril de 1959, White sofreu um acidente quase fatal em uma lambreta, que o debilitou seriamente, fato que coincidiu com a Cúria Romana ter tomado providências para suspender a venda de seu "God and the Unconscious" 37 . Após ter conhecimento do acidente de White, Jung entrou em contato com ele pela primeira vez depois da briga entre eles: "Quanto às minhas dúvidas sobre sua atitude geral, devo mencionar, em

\footnotetext{
${ }^{36} \mathrm{Na}$ primavera de 1955, Emma Jung descobriu que seu câncer era inoperável; conseguiu participar da comemoração de aniversário dos 80 anos de Jung e faleceu em 28 de novembro de 1955.

${ }^{37}$ White fraturou o crânio, quatro costelas, a escápula, perdeu a visão do olho esquerdo e a audição do ouvido esquerdo. Quando seu livro se esgotou, Roma tentou retirar o Imprimatur, por causa do prefácio escrito por Jung, mas no final das contas o livro não foi suprimido (Weldon 2007:210, 293, n137, 197; Lammers 2007a:110-111).
} 
autodefesa, que você se expressou publicamente de maneira tão negativa sobre meu trabalho que realmente não sabia qual seria sua atitude real" (Jung para White, 21 de outubro de 1959, em Lammers 2007a:282). Ao que White respondeu:

Estou um pouco comovido de lhe enviar a afirmação de meu amor por você $[. .$.$] fiquei \& ainda estou profundamente perplexo ao tentar$ compreender quando \& onde eu teria feito isso [...] e, embora [haja] questões sobre as quais não consigo estar de acordo com você, jamais questionaria sua sinceridade (muito menos publicamente), como parece que você questiona ou nega a minha [...] (White para Jung, 18 de março de 1960, em Lammers 2007a:283-284).

Ambos tomaram medidas para uma reconciliação, mas ainda não conseguiam evitar os pontos de discórdia.

Em março de 1960, White recebeu o diagnóstico de câncer intestinal, e Jung, que também não estava muito bem, tendo sofrido uma embolia coronária no mês anterior, e sem saber que o câncer de White era terminal, continuou com a discussão entre eles. Dessa vez, dirigiu-se a White como Jó, sugerindo, talvez, que as dolorosas experiências que White estava sofrendo tinham a ver com o lado tenebroso de Javé:

Uma vez que você está exatamente na situação do Jó sofredor, não vou desempenhar o papel dos amigos dele, nem mesmo do sábio Eliú. Humildemente ofereço a sugestão de que você poderia aplicar seu ponto de vista personalista à sua própria pessoa.

Após uma longa explicação psicológica, Jung terminou a carta de maneira bem amigável: "Penso em você em uma amizade sempre duradoura [...] assim, peço seu perdão, como cabe àquele que foi causa de escândalo e aborrecimento" (Jung para White, 25 março de 1960, em Lammers 2007a:284-286). White ficou muito contente de novamente ter notícias de Jung e, nas semanas finais de sua vida, escreveu mais duas cartas, ainda buscando alguma conclusão intelectual. Na primeira, explicou que quando "Antwort auf Hiob" foi publicado, teve de ser considerado objetivamente, porque apresentava "muitas dificuldades e problemas para muitas pessoas além de mim [...] penso que essas questões não podem ser ignoradas por alguém empenhado em difundir e continuar o maravilhoso trabalho que você iniciou e que 'Antwort' parece implicitamente repudiar" (White para Jung, 6 maio de 1960, em Lammers 2007a:289. 291).

Na última carta, escrita dois dias depois, White concluiu:

Hoje tenho plena convicção da importância de seu trabalho pioneiro para a humanidade, mesmo para aqueles que não concordam com todas as suas palavras, mas têm que participar com você da "discussão dialética" [...] Não sei se é verdade que você foi uma "petrus scandali" para mim (como afirma ter sido), mas, na medida em que tenha sido, penso poder afirmar honestamente que sou grato por isso (White para Jung, 8 de maio de 1960, em Lammers 2007a:291-292). 
Victor White morreu duas semanas após essa carta, aos 57 anos de idade, e Jung sobreviveu a ele por apenas um ano ${ }^{38}$.

A trajetória da relação pessoal Jung-White e de sua colisão intelectual a respeito da natureza do mal provocou perdas e sofrimento substanciais ${ }^{39}$. $O$ grau do envolvimento entre eles, a intensidade da discussão e a magnitude de sua interação levaram à hipótese psicológica de que os eventos cruciais relacionados a ambos não eram alheios aos fenômenos que estavam discutindo. Lammers escreveu sobre um campo de força que tomou conta de ambos e a tragédia deles foi compartilhada (Lammers 2005:9). Especialista em White e diretor do departamento de teologia da Universidade de Lancaster, Adrian Cunningham, acredita que a vida de White foi abreviada pela discussão e desentendimentos com Jung (Cunningham 1981:324). John Dourley, padre católico e analista junguiano, concorda com o ponto de vista de Jung ${ }^{40}$ de que White não conseguiu fazer a transição oferecida pela psicologia e escolheu a transformação da morte (Dourley 2009:85).

Dessa forma, seria válido especular se a polêmica Jung-White tornou-se um testemunho vivo do "drama pleromático, cujo coro trágico é constituído pela humanidade", conforme discutido em "Answer to Job"? (Jung 1952, ATJ, CW1 1: §686) O que é possível afirmar é que o impacto da argumentação de Jung contra a privatio foi enorme para White. Com a publicação de "Answer to Job", o problema do mal foi empurrado para Deus e tornou-se impossível para White aceitar que existe o mal no Deus transcendente de sua fé. Na lógica tomista de White, Bondade Divina e Existência eram a mesma coisa, ou seja, tudo aquilo que foi criado por Deus tem essência e é, por conseguinte, bom. A insistência de Jung de tornar o mal real, com essência própria e não como uma ausência de bem, fez com que o mal adquirisse o status do bem ${ }^{41}$. As implicações de tal posição, de compreender a divisão entre bem e mal como reflexo de uma contradição no próprio criador, mostraram-se incompatíveis com seu ponto de vista religioso, uma vez que a crença na bondade de Deus é absolutamente vital e central para a fé cristã. Em "Answer to Job", Jung corrompeu a verdade cristã de que o mal é proveniente dos homens, não de Deus, e inverteu a doutrina tradicional de homem à imagem de Deus, para Deus à imagem do homem. Assim a interpretação herética de Jung postulou a ideia de que a humanidade está

\footnotetext{
${ }^{38}$ Victor White morreu em 22 maio de 1960 e Jung em 06 junho de 1961.

${ }^{39}$ Começou com a embolia coronária de Jung um ano antes do encontro com White, em 1946; seguida pela destruição gradual da carreira de White; depois pelo câncer terminal e falecimento de Emma Jung em 1955; em seguida, pelo acidente de lambreta quase fatal de White em 1959; depois por outra embolia coronária de Jung em 1960; e, finalmente, pelo câncer e morte prematura de White em 1960.

${ }^{40} J u n g$ descreveu isso em uma carta sobre White: "Tenho visto um número significativo de pessoas que morrem em uma época de grande transição, chegando, por assim dizer, ao fim da peregrinação em direção aos Portões, onde o caminho se bifurca para a terra do Além e para o futuro da humanidade e sua aventura espiritual" (Jung, em Lammers 2007a:306).

${ }^{41}$ Lammers oferece uma importante distinção conceitual sobre o problema do mal na obra de Jung que teria ajudado White a melhor compreender Jung. Ela fez uma distinção entre dois tipos de mal: o mal do mito e o mal da história. Para Jung, o primeiro contém uma interação dinâmica de opostos que precisam um do outro, como as mãos esquerda e direita de Deus e o símbolo do yin e yang. O segundo consiste em todos os horrores dos eventos históricos e das guerras, que demonstram a capacidade humana de ações destrutivas e dano real. "O mal mítico precisa ser enfrentado, de modo a que os males históricos possam ser combatidos" (Lammers 1994: 180-184).
} 
colocada no contexto das polaridades e contradições da Imago Dei que, da mesma forma, correspondem aos aspectos positivo e negativo da natureza humana.

Para White, a transformação da imagem ocidental de Deus aplica-se aos seres humanos, não a Deus; porém, para Jung, a Imago Dei ocidental tem tanto um lado sombrio como um potencial para transformação. Embora a discussão entre eles "tenha gerado mais calor do que luz" (White 1952:75, n1), e que a distância entre o pensamento de ambos não tenha podido ser superada, foi a incompatibilidade entre os pontos de vista dos dois e de seus esforços para se educarem mutuamente que ajudaram Jung a formular seu pensamento da maturidade (Stein 2007:x). White, como um catalizador e como a "centelha que acendeu" (Stein 2003:16) o repúdio apaixonado de Jung à privatio boni e o prolongado diálogo dos dois, parece ter sido uma "influência formativa" em "Answer to Job" e em trabalhos alquímicos posteriores de Jung (Dourley 2007:283). Não obstante as acusações de White, Jung nunca foi um dualista e estava "profundamente convencido da unidade do Self" (Jung, em Lammers 2007a: 142). Na verdade, a sua psicologia respondeu ao dualismo que observou "à espreita, nas sombras da doutrina cristã" (Ibid.). Pode-se talvez afirmar que sua imaginação religiosa do Self como uma complexio oppositorum o transforme em um monista de duplo-aspecto, onde o mito evolutivo da necessária encarnação de Deus não coloca os opostos "Deus" e "homem" como eram antes; em vez disso, os opostos estão dentro da própria Imago Dei (Jung, MDR:370-371).

\section{Conclusão}

A questão sobre se o mal é um fenômeno humano ou se tem uma estrutura metafísica ainda paira sobre o mundo pós-cristão e o mundo pós-junguiano. Seja como for, do ponto de vista psicológico, "Answer to Job" pode ser vivenciado como uma "taça de sofrimento" servida ao homem moderno comum e mortal, com a qual a "conta da era cristã nos é apresentada" (Jung , CW18: §1661). O cristianismo herdou as contradições de Javé, personificadas na oposição metafísica entre Cristo e Satanás (Dourley 2007:284). Nessa divisão, Cristo encarnou o lado bom de Deus e, presumivelmente, livrou a humanidade do mal. Entretanto,

o Deus tenebroso colocou nas mãos [do homem] a bomba atômica e o material para uma guerra química, dando-lhe assim o poder de despejar a taça da ira apocalíptica sobre seus semelhantes. Como Ihe foi posto nas mãos um poder por assim dizer divino, ele não pode mais continuar cego e inconsciente (Jung 1952, ATJ, CW1 1: §747).

Essas linhas reveladoras anunciam a nova dispensação: a humanidade tornou-se um componente essencial do drama divino e é forçada a tornar-se responsável pela maneira como o lado sombrio de Deus se manifesta por meio da natureza humana. A batalha entre o bem e o mal, a "violenta batalha entre os opostos" deve ser travada dentro da alma do indivíduo (Jung, em Lammers 2007a:264-265; Stein 2007:315). Em outras palavras, enfrentar o mal de maneira mais consciente significa não apenas a aceitação de que cada um de nós contém tanto a escuridão como a luz, como também o autoconhecimento "da soma de atos vergonhosos e bons de que somos capazes" (Jung, MDR: 362).

Hoje em dia ainda estamos, individual e coletivamente, lutando para compreender as motivações patológicas dos atos de maldade e a conexão entre violência e religião. Tanto a história como o atual clima político mostram que, quando o mal irrompe, a violência se multiplica 
e o que normalmente seria reprimido torna-se aceitável; e, no fim, os países entram em guerra. Pior ainda, as consequências e o resultado dos atos malignos são exatamente o que sempre foram: a morte de inocentes, comunidades marginalizadas, milhões de refugiados com pouquíssima esperança de uma resolução realista.

No cerne de "Answer to Job", de Jung, havia uma mensagem premente, válida em sua época e válida ainda hoje:

Defrontamo-nos com coisas tão espantosas e chocantes que se tornou candente a questão de saber se tal fato pode harmonizar-se com a ideia de um Deus de bondade. Não se trata de um problema que interessa apenas aos especialistas em teologia, mas de um pesadelo religioso e humano em geral, para cujo estudo um leigo em teologia como eu pode, também, trazer a sua palavra de contribuição (Jung 1952, ATJ, CW1 1: §736).

Tal preocupação traz esse tópico para mais perto da pesquisa e do debate contemporâneos sobre uma nova era geológica, o Antropoceno ${ }^{42}$. Simon L. Lewis (professor de Ciência da Mudança Global) e Mark A. Maslin (professor de Ciência dos Sistemas Terrestres), ambos da University College, em Londres, assinalaram que o sinal químico da cinza nuclear (nuclear fallout) é um dos muitos impactos humanos sobre o meio ambiente. Em 2015, foi proposto um novo modelo, que reconhece a primeira demonstração de uma arma nuclear como marcador do término de uma época anterior, o Holoceno, e o início de uma nova era, o Antropoceno: "a explosão nuclear realizada em 16 julho de 1945 no deserto Jornada del Muerto, no Novo México, é o marco zero do Antropoceno" (Lewis \& Maslin 2018:291). A evidência científica de que o poder das ações humanas criou uma nova era geológica de alguma forma confirma o ponto de vista de Jung de que mesmo a sombra mais tenebrosa representa um aspecto de cada um de nós.

\section{Referências}

Aquinas, T. (1993). Selected philosophical writings (T. McDermott, selec., trad.). Oxford: Oxford University Press.

Aristotle. (1933). The metaphysics (H. Tredennick, transl., Books I-IX, Loeb Classical Library, $\left.\mathrm{n}^{\circ} 271\right)$. Cambridge, Mass: Harvard University Press.

\footnotetext{
${ }^{42}$ Combinando as palavras gregas para "humano" e "época recente", os cientistas deram a esse novo período o nome de Antropoceno. Descreve o período no qual o Homo sapiens tornou-se um superpoder geológico, colocando a Terra em uma nova direção em seu longo desenvolvimento. O Antropoceno é um ponto de inflexão na história da humanidade, na história da vida e na história da própria Terra. É um novo capítulo na crônica da vida e um novo capítulo na história humana (Lewis e Maslin 2018:5).
} 
Arrai, T. (2015). Profiles in Jungian-Christian dialogue with Adrian Cunningham: DVD (transcript online). Recuperado 11 nov. 2020, de http://www.innerexplorations.com/catjc/3.htm.

Augustine. (1912). Confessions (W. Watts, transl., Books I-VIII, Loeb Classical Library, $\left.n^{\circ} 26\right)$. Cambridge, Mass: Harvard University Press.

Bair, D. (2003). Jung: a biography. Boston: Little Brown.

Bishop, P. (2002). Jung's answer to Job: a commentary. London: Routledge.

Brooks, R. M. (2011). Un-thought out metaphysics in analytical psychology: a critique of Jung's epistemological basis for psychic reality. Journal of Analytical Psychology 56(4), 492-513. https://doi.org/10.1111/i.14685922.201 1.01925.x

Buber, M. (1952). Eclipse of God: studies in the relation between religion and philosophy. New York: Harper and Row.

Bulkeley, K., \& Weldon, C. (Eds.). (2011). Teaching Jung. Oxford: Oxford University Press.

Chase, S. (2013). Job: a theological commentary on the Bible. Lovisville: Westminster John Knox Press.

Corey, L. (1990). For the sake of God: a reply to Jung. San Francisco Jung Institute Library Journal 9(1), 27-37.

https://doi.org/10.1525/jung.1.1990.9.1.27

Cunningham, A. (1981). Victor White and C.G. Jung: the fateful encounter of the white raven and the gnostic. New Blackfriars 62(733-734), 320-334.

Cunningham, A. (2007). Victor White: a memoir (Appendix 5, pp. 307-336). In Lammers, A., \& Cunningham, A. (Eds.). The Jung-White letters. London: Routledge.

Davies, B. (Ed.). (2001). The 'de malo' of Thomas Aquinas. Oxford: Oxford University Press.

Dourley, J. (2007). The Jung-White dialogue and why it couldn't work and won't go away. Journal of Analytical Psychology 52(3), 275-295.

https://doi.org/10.1111/j.1468-5922.2007.00663.x

Dourley, J. (2009). The religious significance of Jung's psychology. International Journal for the Psychology and Religion 5(2), 73-89. https://doi.org/10.1207/s15327582ijpr0502_1

Drob, S. (2012). Reading the Red Book: an interpretive guide to C. G. Jung's Liber Novus. New Orleans: Spring Journal Books.

Edinger, E. (1992a). The creation of consciousness: Jung's myth for modern man. Toronto: Inner City Books.

Edinger, E. (1992b). Transformation of the God-image: an elucidation of Jung's Answer to Job. Toronto: Inner City Books.

Evans, E. (1954). An assessment of Jung's Answer to Job. Guild of Pastoral Psychology 78, 5-26.

Fordham, M. (1955). An appreciation of answer to Job. British Journal of Medical Psychology 28(4), 271-273. 
Gilbert, R. (Ed). (2008). Knowledge of the heart: gnostic movements and secret traditions. Surrey: Lewis Masonic/lan Allan Publishing.

Goethe, J. W. (2007). Faust (J. R. Williams, trans, introd., notes. London: Wordsworth Classic of World Literature.

Hannah, B. (2001). Encounters with the Soul: active imagination as developed by C. G Jung. Brooklyn, NY: Chiron Publications.

Heisig, J. (1973). Jung and theology: a bibliographical essay. Spring, An Annual of Archetypal Psychology and Jungian Thought. 204-55.

Heisig, J. (1979). Imago Dei: a study of C. G. Jung's Psychology of religion. Lewisburg: Bucknell University Press.

Hull, R. F. C. (1971). Bibliographical notes on active imagination in the works of C.G. Jung. Spring, An Annual of Archetypal Psychology and Jungian Thought. 115-120.

Huskinson, L. (Ed.). (2008). Dreaming the myth onwards: new directions in Jungian therapy and thought. London: Routledge.

Jaffé, A. (1975). The myth of meaning. New York: Penguin Books.

Jung, C. G. (1973). C. G. Jung letters (A. Jaffé, org., \& R. F. C. Hull, trans., Vols 1-2, 1906-1961). London: Routledge \& Kegan Paul.

Jung, C. G. ([1921]). Psychological types (CW, Vol. 6). Princeton, NJ: Princeton University Press.

Jung, C. G. ([1951]). Aion: researches of the phenomenology of the self (CW, Vol. 9/ii). Princeton, NJ: Princeton University Press.

Jung, C. G. ([1952]). Answer to Job (CW, Vol. 11). London: Routledge \& Kegan Paul.

Jung, C. G. ([1952/1953]). Foreword to White's God and the unconscious. In Psychology and religion: west and east. (CW, Vol. 11). London: Routledge \& Kegan Paul.

Jung, C. G. ([1953]). Two essays on analytical psychology (CW, Vol. 7). London: Routledge \& Kegan Paul.

Jung, C. G. [1953]. The structure and dynamics of the psyche (CW, vol. 8, 2a ed.). Princeton, NJ: Princeton University Press.

Jung, C. G. ([1954]). The symbolic life, miscellaneous writings (CW, Vol. 18). Princeton, NJ: Princeton University Press.

Jung, C. G. ([1955/1956]). Mysterium coniunctionis (CW, Vol. 14). Princeton, NJ: Princeton University Press.

Jung, C. G. ([1958]). Psychology and religion: west and east (CW, Vol. 11). London: Routledge \& Kegan Paul.

Jung, C. G. ([1964]). Civilization in transition (CW, Vol. 10). London: Routledge \& Kegan Paul.

Jung, C. G. ([1964]). Man and his symbols. London: Aldus Books Limited.

Jung, C. G. ([1968]). Alchemical studies (CW, Vol. 13). Princeton, NJ:

Princeton University Press. 
Jung, C. G. (1989/[1934/1939]). Nietzsche's Zarathustra: notes of the seminar given in 1934-9 (Vol. 2). Princeton, NJ: Princeton University Press.

Jung, C. G. (1995/[1962/1983]). Memories, dreams, reflections (A. Jaffé, ed., R. Winston, \& C. Winston, transl.). London: Routledge \& Kegan Paul, 1963; reprint London: Fontana Press, 1995.

Jung, C. G. (2009). The red book: liber novus (S. Shamdasani, ed. and introd.). London \& New York: W.W. Norton \& Company.

Jung, C. G. 2010. Answer to Job, with a foreword by Sonu Shamdasani. Princeton: Princeton University Press.

Kille, A D. (2001). Psychological biblical criticism. Minneapolis: Augsburg Fortress.

Kings, S. (1997). Jung's hermeneutics of scripture. Journal of Religion,77(2), 233-251. https://www.jstor.org/stable/1205771

Lambert, K. (1955). Review: Jung's answer to Job. Journal of Analytical Psychology 7 (1), 100-108.

Lammers, A. (1994). In God's shadow: the collaboration of Victor White and C.G. Jung. Mahwah, NJ: Paulist Press.

Lammers, A. 2005. "The missing fourth" in the Jung-White letters. Guild of Pastoral Psychology 287, 1-24.

Lammers, A, \& Cunningham, A. (Eds). (2007a). The Jung-White Letters. London: Routledge.

Lammers, A. (2007b). Jung and White and the God of terrible double aspect. Journal of Analytical Psychology 52(3), 253-274.

https://doi.org/10.1111/j.1468-5922.2007.00662.x

Lévy-Valensi, É. (1991). Job: réponse à Jung. Paris: Éditions du Cerf.

Lewis, S. \& Maslin, M. (2018). The human planet: how we created the anthropocene. London: Penguin Random House.

Livingston, J. C. (1997). Modern christian thought: the enlightenment and the Nineteenth Century (Vol. 1). New Jersey: Prentice-Hall.

Livingston, J. C. (2000). Modern christian thought: the twentieth century (Vol. 2). New Jersey: Prentice-Hall.

MacKenna, C. (2008). Jung's "White Raven": review: the Jung-White letters. British Journal of Psychotherapy 24(3), 365-379. https://doi.org/10.1111/j.1752-0118.2008.00091.x

Maillard, C. (2011). La penseé de Carl Gustav Jung et les courants néognostiques de la première moitié du XXème siècle. In Arts, sciences et psychologie: l'élaboration de la pensée de Carl Gustav Jung entre 'Fin de siècle' et Première Guerre mondiale: autour du Livre Rouge (Recherches Germaniques, n 8, pp. 99-116) Strasbourg. [n. n.].

Maillard, C. (2014). Jung's "Seven sermons to the Dead" (1916): a gnosis for modernity: a multicultural vision of spirituality, In T. Kirsch, \& G. Hogenson (Eds.) The red book: reflections on C. G. Jung's liber novus (pp. 81-93). London: Routledge. 
Maillard, C. 2017. Au cœur du Livre Rouge: les sept sermons aux morts. Paris: La Compagnie du Livre Rouge.

McGuire, W., \& R. F. C. Hull. (Eds). (1977). C.G. Jung speaking: interviews and encounters (Bollingen series) Princeton: Princeton University Press.

Meyer, W. (2008). Birthpangs of a christianity for the future?: review of: the Jung-White letters. Jung Journal: Culture \& Psyche 2(4), 95-97.

Miller, D. L. (1995). Jung and the interpretation of the Bible. New York: Continuum.

Nagy, M. (1991). Philosophical issues in the psychology of C.G. Jung. New York: State of University Press.

Naso, R., \& Mills, J. (2016). Ethics of evil: psychoanalytic investigations. London, New York: Routledge.

Naso, R., \& Mills, J. (2016). Humanizing evil: psychoanalytic, philosophical and clinical perspectives. London, New York: Routledge.

Oglesby, Les. 2017. C. G. Jung and Hans urs von Balthasar: God and evil: a critical comparison. Hove: Routledge.

Owens, L. S. (2010). The hermeneutics of vision: C.G. Jung and Liber Novus. The Gnostic: A Journal of Gnosticism, Western Esotericism and Spirituality (3), 23-36.

Parsons, G. (1981). The structure and purpose of the Book of Job. Biblioteca Sacra 138 (550), 139-157.

Parsons, G. (1981). Literary features of the Book of Job. Biblioteca Sacra 138 (551), 213-229.

Ribi, A. (2013). The search for roots: C.G. Jung and the tradition of gnosis. Los Angeles: Gnosis Archive Books.

Rollins, W. G. (1983). Jung and the Bible. Louisville, KY: Westminster John Knox Press.

Rollins, W. G. (1999). Soul and psyche: the Bible in psychological perspective. Minneapolis: Augsburg Fortress.

Rutte, J. (2009). The White-Jung friendship: the untold story. Psychological Perspectives 52 (3), 292-314.

Schlamm, L. (2004). Review: Jung's Answer to Job: a commentary. Harvest: Journal of Jungian Studies 50 (2), 181 -195.

Schlamm, L. (2008a). Active imagination in Answer to Job. In L. Huskinson (Ed.). Dreaming the myth onwards: new directions in Jungian therapy and thought (pp. 109-121). London: Routledge.

Sedgwick, D. (2002). Answer to Job revisited: Jung on the problem of evil. The San Francisco Jung Institute Library Journal 21 (3), 5-22.

Shamdasani, S. (1995). Memories, dreams, omissions. Spring: A Journal of Archetype and Culture (57), $111-132$. 
Shamdasani, S. (2010). Foreword (pp. vii-x). In Jung: Answer to Job. Princeton: Princeton University Press.

Shamdasani, S. (2009). Introduction. In: The Red Book: Liber Novus. London, New York: W.W. Norton \& Company.

Shamdasani, S. (2012). C. G. Jung: a biography in books. New York, NY: W.W. Norton \& Company.

Spiegelman, M. (2006). C. G. Jung's Answer to Job: a half century later. Journal of Jungian Theory and Practice 8 (1), 1-17.

Stein, M. (1995). Jung on evil. Hove: Routledge.

Stein, M. (2003). The role of Victor White in C. G. Jung's Writings. Guild of Pastoral Psychology 285, 1-24.

Stein, M. (2007a). Of texts and contexts: reflections upon the publication of The Jung-White Letters', Journal of Analytical Psychology 52 (3), 297-319.

Stein, M. (2007b). Foreword (pp. ix-xi). In Lammers, A., \& Cunningham, Adrian. (Eds.). The Jung-White letters. London: Routledge.

Stein, M., \& Raya, J. (Eds.). (2010). Cultures and identities in transition. London: Routledge.

Stein, M. (201 1). Fr. Victor White OP.: the story of Jung's "White Raven" (review). The Catholic Historical Review 97 (3), 601-602. https://doi.org/10.1353/cat.2011.0104

Tardieu, M. (2009). Manichaeism. Illinois: University of Illinois Press.

Von Franz, M-L. 1995. Shadow and evil in fairy tales. Boston: Shambhala.

Von Franz, M-L. (1997). Psychotherapy. Boston: Shambhala.

Von Franz, M-L. (1998). C.G. Jung: his myth in our time. Toronto: Inner City Books.

Weldon, C. (2007). Fr. Victor White OP.: the story of Jung's 'White Raven'. Scranton, PA: University of Scranton Press.

Weldon, C. (2010). Types of thomists: Victor White's use of Aquinas exemplary of a dialectical synthesis (pp. 175-182). In Stein, M., \& Raya J. (Eds.). Cultures and identities in transition. London: Routledge.

Weldon, C. (2011). God on the couch (pp. 115-125). In Bulkeley, K., \& Weldon, C. (Eds.). Teaching Jung. Oxford: Oxford University Press.

White, V. (1949). Eranos: 1947/1948. Dominican Studies (4), 395-400.

White, V. (1952). God and the unconscious. London: Harvill Press.

White, V. (1960). Soul and psyche: an enquiry into the relationship of psychotherapy and religion. New York: Harper.

White, V. (2007). Jung on Job (Appendix 6, pp. 349-356). In Lammers, A., \& Cunningham, A. (Eds.). The Jung-White letters. London: Routledge. 